\begin{tabular}{|c|c|}
\hline $\begin{array}{l}\text { 2. To: (Receiving Organization) } \\
\text { Integration \& Basel ine Management }\end{array}$ & $\begin{array}{l}\text { 3. From: (Originating Organization) } \\
\text { TWRS Facility Ops Design Authority }\end{array}$ \\
\hline $\begin{array}{l}\text { 5. Proj./Prog./Dept./Div.: } \\
\text { Tank Farms / } 74740\end{array}$ & $\begin{array}{l}\text { 6. Design Authority/ Design Agent/Cog. } \\
\text { Engr.: } \\
\text { J. R. Kriskovich }\end{array}$ \\
\hline
\end{tabular}

8. Originator Remarks:

This report provides the results of an Upgrades Needs

Analys is that was performed on Single-Shell Tank (SST)

Ventilation Systems. The current type and status of each

SST ventilation system was identified and evaluated against

current and projected authorization basis requirements.

11. Receiver Remarks: 11A. Design Basel ine Document? [] Yes [X] No

The attached report was written to comply with the

objectives of the Hanford Federal Facility Agreement and

Consent Order, Tri-Party Agreement Milestone M-43-03.

4. Related EOT No.:

$N / A$

7. Purchase Order No.:

N/A

9. Equip./Component Mo.:

N/A

10. System/Bldg./Facility:

SST Ventilation Systems

12. Major Assm. Dig. No.:

$N / A$

13. Permit/Permit Application No.: N/A

14. Required Response Date: $02 / 07 / 97$

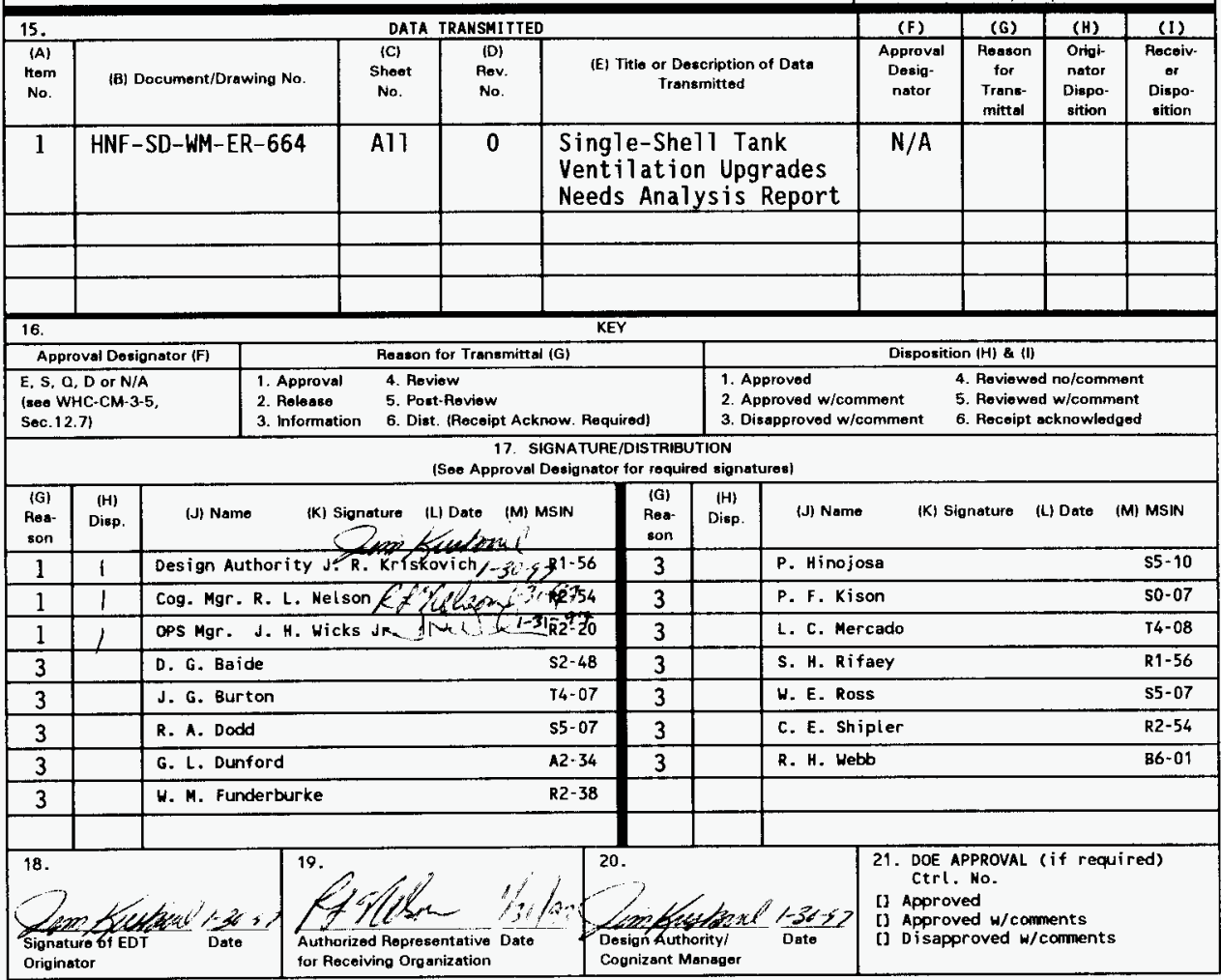

BD-7400-172-2 (05/96) GEF097 


\title{
Single-Shell Tank Ventilation Upgrades Needs Analysis Report
}

\author{
J. R. Kriskovich \\ Lockheed Martin Hanford Company, Richland, WA 99352 \\ U.S. Department of Energy Contract DE-AC06-87RL10930
}

$\begin{array}{lll}\text { EDT/ECN: } 613432 & \text { UC: } 2050 \\ \text { Org Code: } 74740 & \text { Charge Code: } & \text { N1079 } \\ \text { B\&R Code: EW3120071 } & \text { Total Pages: } 66\end{array}$

Key Words: Single-Shell Tank, Ventilation, Fan, Tri-Party Agreement, Milestone, Assessment, Flammable Gas, Standing Order, Authorization Basis

Abstract:

This report was written to comply with the objectives of the Hanford Federal Facility Agreement and Consent Order, Tri-Party Agreement Milestone M-43-03 "Provide to the Washington State Department of Ecology and Department of Health the Results of the Single-Shell Tank Ventilation Upgrades Needs Analysis". The needs analysis consists of identifying the current type and status of each single-shell tank ventilation system, identifying current and projected authorization basis requirements, and identifying ventilation system compliance deficiencies.

TRADEMARK DISCLAIMER. Reference here in to any specific comercial product, process, or service by trade name, trademark, manufacturer, or otherwise, does not necessarily const itute or imply its endorsenent, recommendation, or favoring by the United States Goverment or any agency thereof or its contractors or subcontractors.

Printed in the United States of America. To obtain copies of this document, contact: WHC/BCS Document Control Services, P.0. Box 1970, Mailstop H6-08, Richland WA 99352, Phone (509) 372-2420; Fax (509) 376-4989.
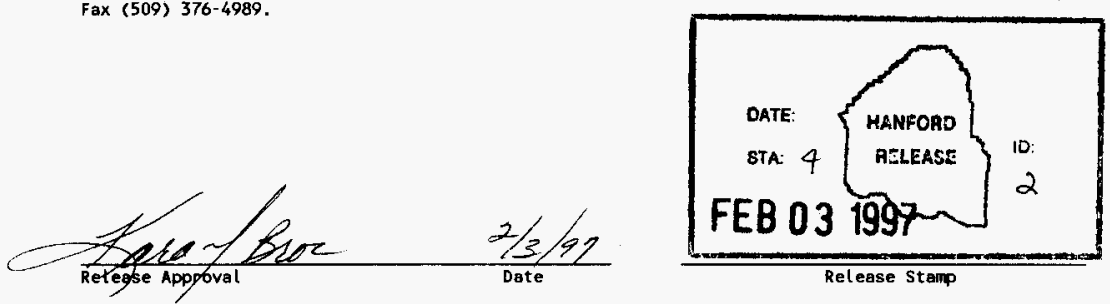

Release Stamp 


\section{SINGLE-SHELL TANK VENTILATION UPGRADES}

\section{NEEDS ANALYSIS REPORT}

January 6,1997

Prepared by:

Parsons Infrastructure \& Technology Group, inc. 1955 Jadwin Avenue

Richland, Washington 99352 
HNF-SD-WM-ER-664, Rev. 0

\section{EXECUTIVE SUMMARY}

This report was written to comply with the objectives of the Hanford Federal Facility Agreement and Consent Order (DOE/RL 1994a), Tri-Party Agreement (TPA) Milestone M-43-03 "Provide to the Washington State Department of Ecology and Department of Health the Results of the Single-Shell Tank Ventilation Upgrades Needs Analysis" by providing the subject report. The needs analysis consists of identifying the current type and status of each single-shell tank (SST) ventilation system, identifying current and projected authorization basis requirements, and identifying ventilation system compliance deficiencies. Other requirements (i.e., environmental, design, testing, etc.) are identified and specifically addressed in Tank Farm Restoration and Safe Operations Initial Assessment Report HVAC Systems (WHC 1996k).

The U.S. Department of Energy (DOE) established the Tank Waste Remediation System (TWRS) program to manage and dispose of the waste contained in underground storage tanks at the Hanford Site. There are 177 underground waste storage tanks of which 149 are SSTs in 12 distinct tank farms. There are 28 double-shell tanks (DSTs). One hundred thirty-four of the SSTs have passive ventilation systems, while 15 are actively ventilated. Currently 115 of the SSTs have already had most of the liquid removed (WHC 1996i).

The current authorization basis documents identifying SST ventilation system requirements include the Single-Shell Tank Interim Operational Safety Requirements (WHC 1994a) (IOSR), the West Tank Farms Standing Order (FDH 1996a) (S/O), and the East Tank Farms Standing Order (FDH 1996b) (S/O). However, through an effort to enhance operational safety, TWRS is implementing the Tank Waste Remediation System Basis for Interim Operation (WHC 1996b) (BIO), Tank Waste Remediation System Technical Safety Requirements (WHC 1996c) (TSR) and Tank Waste Remediation System Safety Structures, Systems, and Components:

Requirements and Characteristics (WHC 1996d) (SSC). These documents are being reviewed by the DOE for approval and will provide the authorization basis for operation until the Final Safety Analysis Report (FSAR) is released. Additionally, each SST's ventilation system will be evaluated according to the Interim Stabilization (IS) requirements that are defined in the Controlled, Clean, and Stable Design Requirements Document for Single-Shell Tanks (WHC 1996e).

All SSTs are ventilated by either a passive or an active exhaust system to prevent over pressurization. The primary functions of the ventilation systems are two-fold: 1) mitigate the vapor space ignition risk by maintaining flammable gas levels less than the safety limit, and 2) remove radioactive decay heat to limit waste temperatures and preserve tank structural integrity. All ventilation systems include High Efficiency Particulate Air (HEPA) filters in the inlet and exhaust paths to eliminate the risk of releasing airborne particles. The passive systems rely on changes in atmospheric pressure to exchange the tank vapors with outside air. The active systems use an exhaust fan to pull vapors from the tank. Ambient air replaces the tank vapors through an inlet HEPA filter. This assures that vapors exiting the tank are properly filtered when the ventilation fan is not operating.

The current SST passive ventilation systems have been evaluated (WHC 1996a) and found to be satisfactory for controlling steady-state flammable gas. Active ventilation systems that are to be installed on tanks C-105 and C-106 in support of the W-320 Project are satisfactory. However, the ventilation system supporting tanks SX-101 through SX-112 and SX-114 have components that have exceeded their design life by at least 17 years. This system requires further evaluation to verify its functional capabilities to verify its capability to mitigate flammable gas concerns and 
a risk assessment be performed on the SX-farm active ventilation system. All SST operations are required to comply with the West/East Tank Farms S/O (FDH 1996a, FDH 1996b) requirements for flammable gas controls. Table 1 provides a summary matrix of this needs analysis.

To support the IS function, control instrumentation upgrades with connections to the Tank Monitoring and Control System (TMACS) are required for SSTs that continue to require active ventilation. The passively ventilated systems will adequately support is with minor changes which can be accomplished through continuing maintenance activities.

Ventilation requirements for other SST operations and activities such as waste sampling, stabilization, and retrieval will be evaluated on a case basis. It is expected that most of these activities will use individually engineered ventilation systems which have been designed specifically for the activity and will meet the requirements of the West/East Tank Farms S/O (FDH 1996a, FDH 1996b) or the current authorization basis.

A FSAR is currently being generated. The FSAR accident scenarios are similar to those calculated for the Tank Waste Remediation System Basis for Interim Operation (WHC 1996b), and there is no indication that the approved requirement set will change the SST ventilation criteria or require extensive upgrades. Following DOE Headquarters approval of the FSAR, it is recommended that SST ventilation systems be reviewed to ensure compliance with the FSAR.

The intended users of this report include Hanford Site Tank Farm personnel, DOE, the Washington State Departments of Ecology (Ecology) and Health (WDOH) and the public. 
HNF-SD-WM-ER-664, Rev. 0

Table 1. SST Ventilation System Summary.

\begin{tabular}{|c|c|}
\hline A Total of 149 SSTs & NUMBER \\
\hline SSTs Passively Ventilated & 134 \\
\hline SSTs Actively Ventilated & $15^{\star}$ \\
\hline Active Ventilation Systems & ${ }^{2}$ (C-farm, SX-farm) \\
\hline NEEDS ANALYSIS CONCLUSIONS & NUMBER \\
\hline Continue to maintain present status & 134 \\
\hline $\begin{array}{l}\text { SSTs Undergoing Ventilation System } \\
\text { Modification }\end{array}$ & $\begin{array}{c}2 \\
\text { (C-farm under Project } \\
\text { W-320) }\end{array}$ \\
\hline Recommend Risk Assessment & $\begin{array}{c}13 \\
\text { (all in SX-farm; one } \\
\text { system) }\end{array}$ \\
\hline $\begin{array}{l}\text { Modifications required to comply with } \\
\text { Interim Stabilization (IS) requirements }\end{array}$ & $\begin{array}{l}13 \\
\text { (all in SX-farm; } \\
\text { assuming the upgraded } \\
\text { C-farm ventilation } \\
\text { system meets IS } \\
\text { requirements) }\end{array}$ \\
\hline
\end{tabular}

*Thirteen (13) tanks are connected through cascade lines to one ventilation system in SX-farm. Two (2) tanks are connected through a cascade line to one ventilation system in C-farm. 


\section{TABLE OF CONTENTS}

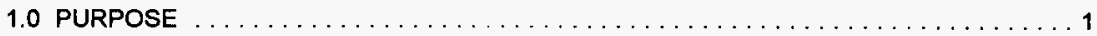

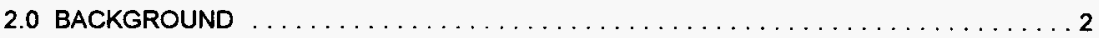

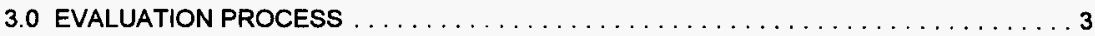

4.0 VENTILATION REQUIREMENTS AND EXISTING CONDITIONS $\ldots \ldots \ldots \ldots \ldots \ldots$

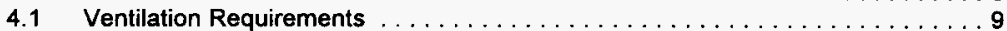

4.1.1 Interim Operational Safety Requirements (IOSRs) . . . . . . . . . . . 9

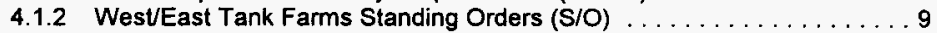

4.1.3 TWRS Safety Systems, Structures, and Components (SSCs):

Requirements and Characteristics . . . . . . . . . . . . . . 10

4.1.4 TWRS Technical Safety Requirements (TSR) . . . . . . . . . . . . . . 10

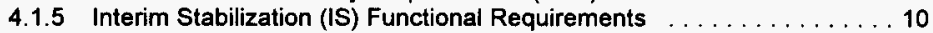

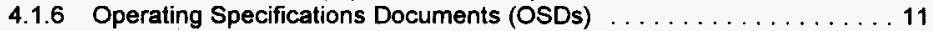

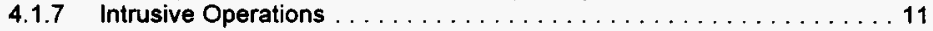

4.2 Existing Condition . . . . . . . . . . . . . . . 12

5.0 CONCLUSIONS AND RECOMMENDATIONS $\ldots \ldots \ldots \ldots \ldots \ldots \ldots \ldots \ldots$

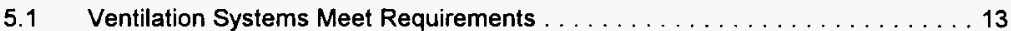

5.2 is Criteria . . . . . . . . . . . . . . . . . . . . . . . 13

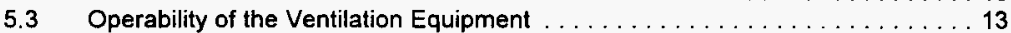

5.4 Recommendations for Continued Safe Operation of SSTs . . . . . . . . 13

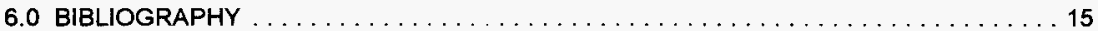

\section{LIST OF TABLES}

Table 3.1 SST Ventilation System Authorization Basis Document Matrix

\section{LIST OF FIGURES}

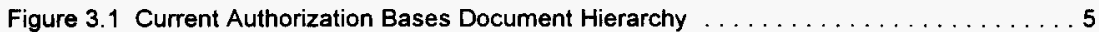

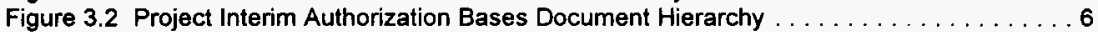

Figure 3.3 Single-Shell Tank Needs Analysis Logic Flowchart $\ldots \ldots \ldots \ldots \ldots \ldots \ldots \ldots \ldots$ 
HNF-SD-WM-ER-664, Rev. 0

\title{
TABLE OF CONTENTS (Continued)
}

\author{
Appendices
}

A SST Compliance Determination and Status Summary for Single-Shell Tank Ventilation Systems

B Functional Requirements from Single-Shell Tank Interim Operational Safety Requirements

C Functional Requirements from West/East Tank Farms Standing Orders

D Functional Requirements from Tank Waste Remediation System Safety Structures, Systems, and Components:

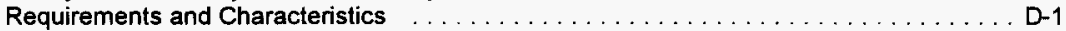

E Functional Requirements from Tank Waste Remediation System

Technical Safety Requirements . . . . . . . . . . . . . . . . . . . . .

F Interim Stabilization Functional Requirements $\ldots \ldots \ldots \ldots \ldots \ldots \ldots \ldots \ldots \ldots$

G Functional Guidelines from the Tank Waste Remediation System Operational Specifications Documents $\ldots \ldots \ldots \ldots \ldots \ldots \ldots \ldots \ldots \ldots \ldots \ldots \ldots$

$\mathrm{H}$ Preliminary Cost Estimates . . . . . . . . . . . . . . . . . . . . H-1 


\section{ACRONYMS}

$\begin{array}{ll}\text { BIO } & \text { Basis of Interim Operation } \\ \text { CAM } & \text { Continuous Air Monitor } \\ \text { CCS } & \text { Controlled, Clean, and Stable } \\ \text { DOE } & \text { Department of Energy } \\ \text { DST } & \text { Double-Shell Tank } \\ \text { ECology } & \text { Washington State Department of Ecology } \\ \text { FSAR } & \text { Final Safety Analysis Report } \\ \text { GRE } & \text { Gas Release Event } \\ \text { HEPA } & \text { High Efficiency Particulate Air } \\ \text { IC } & \text { Ignition Controls } \\ \text { IOSR } & \text { Interim Operational Safety Requirements } \\ \text { IS } & \text { Interim Stabilization } \\ \text { ISSTRS } & \text { Initial Single-Shell Tank Retrieval Systems } \\ \text { JCO } & \text { Justification for Continued Operation } \\ \text { MTBF } & \text { Mean Time Between Failures } \\ \text { RMCS } & \text { Rotary Mode Core Sampling } \\ \text { ROM } & \text { Rough Order of Magnitude } \\ \text { SIO } & \text { Standing Order } \\ \text { SHMS } & \text { Standard Hydrogen Monitoring System } \\ \text { SSC } & \text { Structures, Systems and Components } \\ \text { SST } & \text { Single-Shell Tank } \\ \text { SWP } & \text { Salt Well Pumping } \\ \text { TMACS } & \text { Tank Monitoring and Control System } \\ \text { TPA } & \text { Hanford Federal Facility Agreement and Consent Order or Tri-Party Agreement } \\ \text { TWRS } & \text { Tank Waste Remediation System } \\ \text { TSR } & \text { Technical Safety Requirements } \\ \text { USQ } & \text { Unreviewed Safety Question } \\ \text { WDOH } & \text { Washington State Department of Health } \\ \end{array}$


HNF-SD-WM-ER-664, Rev. 0

\subsection{PURPOSE}

The purpose of this report is to provide a needs analysis of the single-shell tank (SST) ventilation systems and recommended actions to resolve requirement compliance issues. This report documents the SSTs current ventilation system status. Additionally, it evaluates the current and proposed future requirements that might dictate system upgrades. The status of all of the individual tanks are listed and recommended ventilation upgrades which may be needed to maintain safe storage of the tank waste are identified. The scope of the report includes the following tasks:

- Identify the authorization basis dictating SST ventilation system requirements [including projected future authorization basis requirements like the Tank Waste Remediation System Basis for Interim Operation (WHC 1996b), etc.];

- $\quad$ Determine the applicable SST ventilation criteria required to support the safe storage mission, Interim Stabilized (IS);

- Identify non-authorization basis documents such as Operational Specifications Documents (OSDs);

- Assess the current status of SST ventilation systems against the above criteria;

- Identify potential deficiencies of the current SST ventilation systems as identified by the evaluation of the above criteria;

- Identify the ventilation interface requirements for the retrieval function as required; and

- $\quad$ Recommend a preferred path forward where deficiencies are identified. 
HNF-SD-WM-ER-664, Rev. 0

\subsection{BACKGROUND}

From 1943 to 1989 , the Hanford Site's principal mission was the production of weapons-grade plutonium. The chemical separations processes used to extract plutonium generated several hundred thousand metric tons of high-level, transuranic, low-level, hazardous, and mixed waste. Through the early 1960's, this waste was stored in 149 underground SSTs.

The SSTs were designed with a life of approximately 20 years. Leakage of waste from the SSTs to the underlying soil was suspected in 1956 and confirmed in 1961. As a result of the leak, all SSTs were removed from active service with the transfer of waste to the tanks discontinued by November 1980. By the late 1980's, 67 of the SSTs were known or suspected leakers. To address concerns with the tank design, the Hanford Site adopted a double-shell tank (DST) design which provided for increased containment integrity and leak detection. Most of the free-standing liquid contained in the SSTs has been pumped into DSTs (a process called stabilization). However, the remaining solids still contain liquids within their void spaces. At the present time, 115 tanks have been stabilized as a result of most of the surface liquid being removed.

Two issues associated with the storage of the hazardous, radioactive process waste stored in underground storage tanks at the Hanford Site have been identified as follows: 1) increased heat loads, caused by radioactive decay resulting in waste temperatures, that could reduce structural integrity and result in structural failure; and 2) increased flammable gas levels, caused by radiolysis and decomposition of organic waste, located within the tank vapor space and other ex-tank intrusive areas that increase the risk of an explosion. Each SST has undergone extensive surveillance and characterization activities to identify individual risk factors and define the requirements for active or passive ventilation. Both ventilation systems provide evaporative cooling capabilities to mitigate high temperatures and air exchange capabilities to mitigate flammable gas concerns.

The Hanford Federal Facility Agreement and Consent Order (DOE/RL 1994a) was written to support the environmental cleanup of the DOE's Hanford Nuclear Reservation. It is composed of many milestones. Milestone M-43-03 "Provide to the Washington State Department of Ecology and Department of Health the Results of the Single-Shell Tank Ventilation Upgrades Needs Analysis" is the driving factor for this report. 


\subsection{EVALUATION PROCESS}

As mentioned previously, the authorization basis is being modified to enhance safety. Figure 3.1 identifies the current top-level document hierarchy tree, while Figure 3.2 identifies the projected document hierarchy tree for the interim authorization basis. Table 3.1 provides a top-level summary matrix identifying the authorization basis documents that contain requirements relevant to SST ventilation systems. Note that other requirements (i.e., environmental, design, testing, etc.) are identified and specifically addressed in Tank Farm Restoration and Safe Operations Initial Assessment Report HVAC Systems (WHC 1996k).

Each SST was evaluated according to the logic flowchart shown in Figure 3.3. The detailed conclusions are listed in a SST compliance determination and status summary matrix in Appendix A.

The following criteria are identified for this evaluation of SST ventilation systems:

- Flammable Gas Concerns Mest / East Tank Farms Standing Onders (FDH 1996a, FDH 1996b)(S/O)];

- High-Heat Load Requirements [Single-Shell Tank Interim Operational Safety Requirements (WHC 1994a) (IOSR)];

- Safety Structures, Systems, and Components identified from Tank Waste Remediation System Basis for Interim Operation (WHC 1996b) (BIO);

- Technical Safety Requirements [Tank Waste Remediation System Technical Safety Requirements (WHC 1996c) (TSR)];

- Interim Stabilization Requirements from Controlled, Clean, and Stable Design Requirements Document for Single-Shell Tanks (WHC 1996e);

- Operating Specifications for Single-Shell Waste Storage Tanks (WHC 1996g); and

- Operating Specifications for Watch List Tanks (WHC 1996h)

Additionally, the ventilation systems intended for use in SST retrieval activities will be identified. 
HNF-SD-WM-ER-664, Rev. 0

Table 3.1 SST Ventilation System Authorization Basis Document Matrix.

\begin{tabular}{|c|c|c|c|c|c|c|c|c|c|}
\hline & \multicolumn{9}{|c|}{ Authorization Bases Documents / Analysis Criteria } \\
\hline & IOSR & $\begin{array}{c}\mathrm{S} / \mathrm{O} \\
\text { flammable } \\
\text { gas } \\
\text { controls }\end{array}$ & $\begin{array}{l}\mathrm{BIO} \\
\mathrm{SSC}\end{array}$ & $\begin{array}{l}\text { BIO } \\
\text { TSRs }\end{array}$ & IS & $\begin{array}{c}\text { OSD } \\
13\end{array}$ & $\begin{array}{c}\text { OSD } \\
30\end{array}$ & FSAR & $\begin{array}{l}\text { FSAR } \\
\text { TSRs }\end{array}$ \\
\hline \multicolumn{10}{|c|}{ CURRENT (1996) } \\
\hline Requirements & $x$ & $\mathbf{x}$ & & & $\mathbf{x}$ & & & & \\
\hline Guidelines & & & & & & $\mathbf{x}$ & $\mathbf{x}$ & & \\
\hline \multicolumn{10}{|c|}{ PROJECTED (1997 - FSAR) } \\
\hline $\begin{array}{l}\text { Interim } \\
\text { Requirements }\end{array}$ & & & $\mathbf{x}$ & $\mathbf{x}$ & $x$ & & & & \\
\hline Guidelines & & & & & & $P^{*}$ & $?^{*}$ & & \\
\hline \multicolumn{10}{|c|}{ FUTURE } \\
\hline Requirements & & & & & $\mathbf{x}$ & & & $\mathbf{x}$ & $\mathbf{x}$ \\
\hline Guidelines & & & & & & $?^{*}$ & $?^{*}$ & & \\
\hline
\end{tabular}

IOSR -- Single-Shell Tank Interim Operational Safety Requirements (WHC 1994a)

S/O - West Tank Farms Standing Order / East Tank Farms Standing Order (FDH 1996a, FDH 996b)

BIO - Basis for Interim Operation (WHC 1996b)

SSC - Structures, Systems, and Components (WHC 1996d)

TSRs - Technical Safety Requirements (WHC 1996c)

IS - Interim Stabilized (WHC 1996e)

OSD-13 - Operating Specifications for Single-Shell Waste Storage Tanks (WHC 1996g)

OSD-30 -- Operating Specifications for Watch List Tanks (WHC 1996h)

FSAR - Final Safety Analysis Report

"The role that OSDs will have has not yet been determined for the interim authorization basis. 
HNF-SD-WM-ER-664, Rev. 0

Figure 3.1. Current Authorization Basis Document Hierarchy

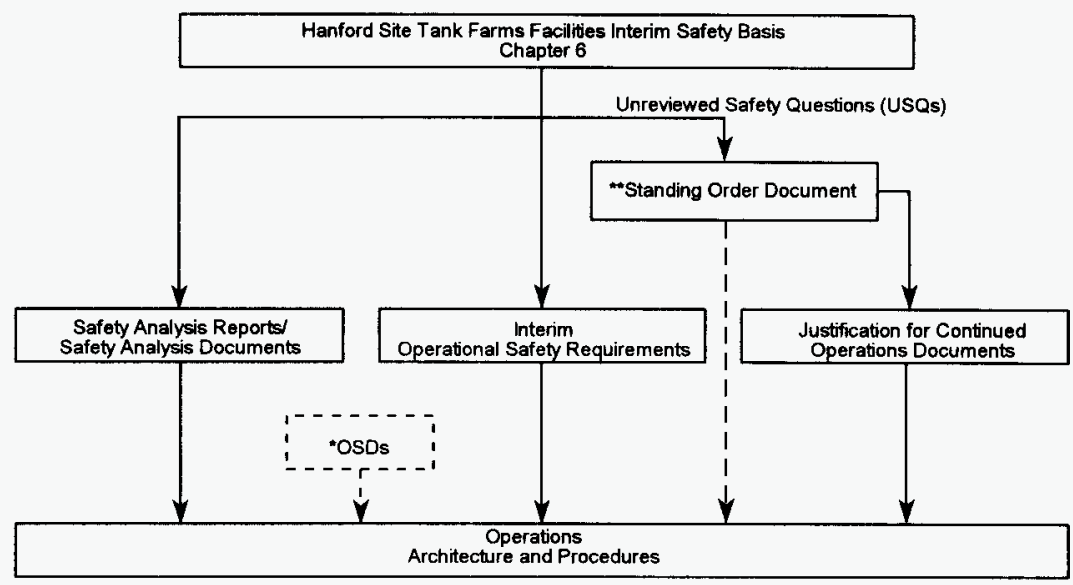

-OSDs - Operational Specifications Documents provide operational guidelines.

*As Required for Continued Operation as a Resuit of a USQ Prior to Justification for Continued Operation Documents being Approved. 
HNF-SD-WM-ER-664, Rev. 0

Figure 3.2. Projected Interim Authorization Bases Document Hierarchy

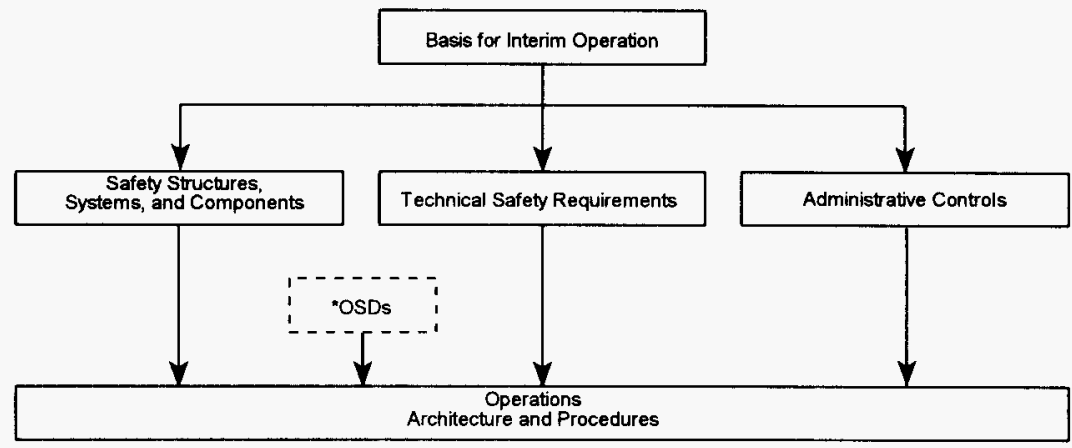

*OSDs - Operational Specifications Documents provide operational guidelines. The specific role of OSDs has yet to be determined in the Interim Authorization Basis. 
HNF-SD-WM-ER-664, Rev. 0

Figure 3.3. Single-Shell Tank Ventilation System Needs Analysis Logic Flowchart

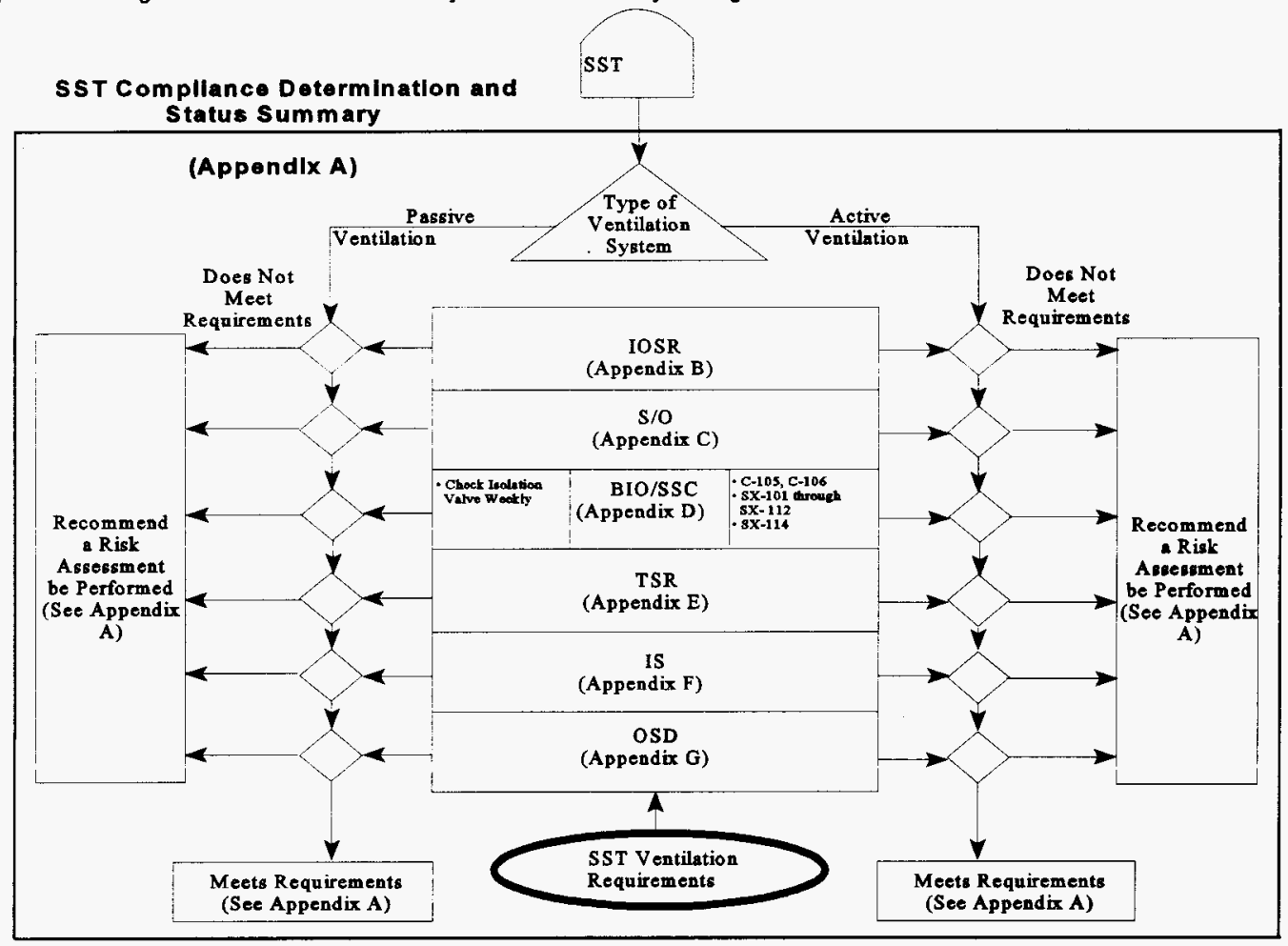


HNF-SD-WM-ER-664, Rev. 0

\subsection{VENTILATION REQUIREMENTS AND EXISTING CONDITIONS}

The current authorization basis identifying SST ventilation system requirements include the Single-Shell Tank Interim Operational Safety Requirements (WHC 1994a) and West/East Tank Farms Standing Orders (FDH 1996a, FDH 1996b). However, TWRS is implementing the Tank Waste Remediation System Basis for Interim Operation (WHC 1996b), Tank Waste Remediation System Technical Safety Requirements (WHC 1996c), and Tank Waste Remediation System Safety Structures, Systems, and Components: Requirements and Characteristics (WHC 1996d) as the interim authorization basis until the FSAR is released. Requirements for Interim Stabilization (IS) are defined in Controlled, Clean, and Stable Design Requirements Document for Single-Shell Tanks (WHC 1996e). Additionally, operating specifications applicable to SST ventilation systems are identified in Operating Specifications for Single-Shell Waste Storage Tanks (WHC 1996g) and Operating Specifications for Watch List Tanks (WHC 1996h).

There are 149 SSTs located within 12 distinct tank farms. One hundred thirty-four (134) of the SSTs have passive ventilation systems, while 15 are actively ventilated. One hundred fifteen (115) SSTs have had most of the surface liquid removed from them and are classified as stabilized (WHC 1996i). Numerous tanks have been placed on a watch list because of flammable gas generation, evolution of organics, ferrocyanide problems, or evolution of heat above and beyond the set limit of $40,000 \mathrm{Btu} / \mathrm{hr}$. Instrumentation such as thermocouples, waste level measurement instruments, etc. have been installed in each tank to allow physical condition monitoring. Additionally, Standard Hydrogen Monitoring System (SHMS) cabinets [some which are connected to the Tank Monitoring and Control System (TMACS)] have been installed on 21 SSTs to monitor the levels of hydrogen. Each tank is reassessed based on the latest surveillance information (measured flammable gas concentrations, increased temperatures, etc.). The latest SST technical data/status is reported in the monthly Waste Tank Summary Report (WHC 1996i). Watch list tank status is identified in Operating Specifications for Watch List Tanks (WHC 1996h).

Summarized descriptions of the following items are provided in this section and the requirements and status matrix in Appendix A:

- Ventilation system authorization basis requirements;

- $\quad$ Status of all SSTs from the latest available references;

- SST stabilization work; and

- Purpose and status of the ventilation system on each tank. 
HNF-SD-WM-ER-664, Rev. 0

\subsection{Ventilation Requirements}

This section discusses the authorization basis safety requirements applicable to SST ventilation systems. For completeness, the actual requirements are provided in each of the appendices.

\subsubsection{Interim Operational Safety Requirements (IOSRs)}

The requirements identified in this document define the acceptable conditions, safe boundaries, bases thereof, and management or administrative controls required to ensure safe operation of the SST facilities. The scope of this document is based on the SST safety analysis reports (SARs) and other documentation. Requirements specific to SST ventilation systems include maintaining the waste temperature below $150^{\circ} \mathrm{C}\left(300^{\circ} \mathrm{F}\right)$ and maintaining required vapor space pressure per each actively ventilated SST, maintaining operable seal loops on each passively ventilated SST, and maintaining exhaust stack radiation monitoring systems on each actively ventilated SST. The specific requirements and limiting conditions of operation as well as the associated implementing document and/or configuration compliance statement are listed in Appendix B.

\subsubsection{West/East Tank Farms Standing Orders (S/O)}

The West/East Tank Farms Standing Order documents (FDH 1996a, FDH 1996b) provide the current authorization basis requirements for operating TWRS relative to flammable gas hazards. This document has been accepted by the TWRS Plant Review Committee and approved by the Department of Energy (DOE). The purpose of this document is to reevaluate and redefine the flammable gas Unreviewed Safety Question (USQ) (DOE/RL 1990) with respect to currently available data and methodology, clarify the applicability of the USQ to additional tanks and other engineered structures within TWRS, and consider additional flammable gas hazards not adequately addressed in the Hanford Site Facilities Interim Safety Basis (WHC 1995a).

Steady state gas releases are managed by diluting and removing the gases from the tank dome space through active or passive ventilation to prevent a steady accumulation of gas to flammable concentrations. Acceptable concentration levels are maintained as low as practical with the existing ventilation configuration. For tanks with a combination of small waste volumes, lowdecay heat loads, small concentrations of organic chemicals, and relatively large dome spaces, steady-state gas releases can be maintained at low concentrations with passive ventilation.

Formal gas samples have been taken from approximately $42 \%$ of the SSTs as of July $1,1996$. An additional $31 \%$ of the SSTs have grab sample results. It is very important to note that the actual steady state gas concentrations measured to date are consistently below $25 \%$ of the LFL. Furthermore, these measurements have demonstrated that the measured values are significantly lower than the calculated values for passively ventilated tanks (WHC 1996a, WHC 1996f). Current ventilation procedures are adequate to mitigate flammable gas concerns and should be continued.

Flammable gas issues have been analyzed and all underground waste storage tanks have been evaluated and categorized in defined groups (facilities Group 1, Group 2, or Group 3) as a result of size and frequency of postulated gas release events. Two (2) sets of Ignition Controls (IC) have been established for operational activities for each group. These activities are described by 1) ex-tank intrusive; 2) dome intrusive; and 3) waste intrusive. Forty-four (44) SSTs are categorized in Group 2 with the remaining 105 categorized in Group 3. 
HNF-SD-WM-ER-664, Rev. 0

Specially engineered ventilation systems are considered for some activities (see section 4.1.6) on a case basis and will incorporate the use of defined Ignition Control Sets as listed in Appendix c.

\subsubsection{TWRS Safety Systems, Structures, and Components (SSCs): Requirements and Characteristics}

The interim authorization basis for operation of TWRS facilities is provided in the Tank Waste Remediation System Basis for Interim Operation (WHC 1996b) (BIO). The BIO (WHC 1996a) will remain in effect until replaced by the new TWRS FSAR and its companion Technical Safety Requirements (TSR) document. The objective of the BIO (WHC 1996a) is to provide an improved interim authorization basis that will immediately enhance safe operation of the TWRS facilities and identify safety systems, structures, and components (SSCs). The SSC requirements and characteristics are documented in TWRS Safety Structures, Systems, and Components: Requirements and Characteristics (WHC 1996d). This document provides ventilation requirements for hardware deflagration controls which were developed to meet the ignition control set requirements established in the S/O (FDH 1996a, FDH 1996b) and specified in the $\mathrm{BIO}$ (WHC 1996b). It is possible that these requirements might change when the FSAR is approved; however, there is no indication that those tanks currently required to be on active ventilation systems will need upgrades to comply with the requirements. The requirements are listed in Appendix D.

\subsubsection{TWRS Technical Safety Requirements (TSR)}

The Tank Waste Remediation System Basis for Interim Operation (WHC 1996a) identifies the operating restrictions and administrative controls that are necessary to preserve the validity of the safety analysis assumptions and to ensure that TWRS is operated within the required conditions bounded by the new analysis and are implemented through the TWRS Technical Safety Requirements (WHC 1996c). The TSRs define the acceptable conditions, safe boundaries, bases thereof, and management or administrative controls required to ensure safe operation during waste storage, transfer, and characterization. Requirements specific to SST ventilation systems include maintaining the ventilation radiation monitoring system on SSTs that are actively ventilated and maintaining active ventilation on the following tanks: C-105, C-106, $S X-114$, and $S X-101$ through $S X-112$. The specific requirements and the associated implementing document and/or configuration compliance statement are listed in Appendix $\mathrm{E}$.

\subsubsection{Interim Stabilization (IS) Functional Requirements}

The TWRS has established the IS project for the SST Farms to reduce safety and environmental risks posed by the tank farms, and to reduce ongoing surveillance and maintenance costs for these same facilities. Interim stabilization ventilation requirements are provided in Controlled, Clean, and Stable Design Requirements Document for Single-Shell Tanks (WHC 1996e). Ventilation system requirements ensure that radioactive gaseous/particulate effluents are controlled in accordance with applicable laws. This is verified through the use of instruments that are remotely read through TMACS. Instruments specific to active ventilation systems include pressure sensing and radiation stack monitoring. The requirements are listed in Appendix F. 
HNF-SD-WM-ER-664, Rev. 0

\subsubsection{Operating Specifications Documents (OSDs)}

Operating specifications are technical limits and controls imposed on a process or operation which, if violated, could jeopardize the safety of personnel and could damage equipment, facilities, the environment, and adversely affect product quality. These documents are not part of the authorization basis; however, the guidelines identified within these are important for consideration. Two OSDs identify specifications specific to SST ventilation systems: Operating Specifications for Single-Shell Waste Storage Tanks (WHC 1996g) and Operating Specifications for Watch List Tanks (WHC 1996h). Specifications identified in these two documents include, but are not limited to, maintaining waste temperature below $150^{\circ} \mathrm{C}\left(300^{\circ} \mathrm{F}\right)$, monitoring waste temperature on tanks with waste greater than $40,000 \mathrm{Btu} / \mathrm{hr}$, monitoring vapor space pressure on each actively ventilated SST, maintaining operable seal loops on each passively ventilated SST, maintaining HEPA filters as required, and using spark-resistant tooling on flammable gas watch list tanks. Specifications from these two documents are listed in Appendix G.

\subsubsection{Intrusive Operations}

4.1.7.1 Rotary Mode Core Sampling (RMCS). The portable exhauster (ventilation system) to support the RMCS operations was designed in 1993. It was designed with

1) flexible ductwork for connection to a tank riser; 2) a heater to lower the relative humidity (which helps reduce condensation); 3 ) a pre-filter which removes larger particles and increases the life of the HEPA filters; 4) a fan; and 5) a stack to disperse the ventilation gas. The RMCS exhauster components are being modified to meet the flammable gas requirements as identified in the RMCS safety analysis document (WHC 1996l). Additionally, the exhauster components meet the interim authorization basis ignition control set requirements (WHC 1996c). Specific design parameters were followed to utilize a non-sparking fan blades/housing and nitrogen purge around normally sparking components (i.e., fan motor). As a result the limiting design requirements, it is difficult to show that it could be installed to support other operations on a continuous basis (e.g., to support saltwell pumping efforts which can take up to three years).

4.1.7.2 Salt-Well Pumping (SWP). The risk of flammable gas releases during SWP of tanks with large amounts of retained gas was judged to be sufficiently uncertain to warrant placing this operation on hold in certain tanks. An initial safety assessment was performed for SWP in Tank 241-A-101 and provides for ventilation system functional design criteria for a portable exhauster. The active ventilation system shall consist of at least a $200 \mathrm{cfm}$ exhauster, its exhauster components meet Class-I, Division-1, Group B NFPA 497A requirements, and be capable of immediate pump deenergization upon exhauster power loss (WHC 1996m). SWP is currently prohibited from operation in SSTs that are identified as Facility Group 2 SSTs in the S/O (FDH 1996a, FDH 1996b). The SSTs are suspected of retaining large amounts of gas based on a gas release event evaluated result of greater than $50 \%$ of the LFL in the headspace (WHC 1996a).

4.1.7.3 Retrieval Activities. Tank waste retrieval from SSTs is divided into near term and medium term operations. Near-term operations include the removal of high-heat waste from the SST C-106 to DST AY-102 through sluicing operations. Project W-320, the Waste Retrieval Sluicing System, will provide its own ventilation system (which must be operational during sluicing operations) while the sluicing operations are performed. While the active ventilation system on C-106 (which is also connected to C-105) is maintained in an operational standby status as a backup for cooling, its main function will be to provide a high-flow exhaust system to support C-106 large riser opening maintenance activities (WHC 1996j). 
The Initial Single-Shell Tank Retrieval Systems (ISSTRS) currently plan on starting retrieval of waste in the following tanks in the year 2003 with approximately one tank per year (in the respective order: 1) $A X-103$; 2) $C-105$; 3) $C-103$; and 4) $A-105$. It is the intent of the ISSTRS program to use the $\mathrm{C}-106$ proof-of-operation and lessons learned to develop and provide ventilation systems that are sufficient to meet the ignition control set requirements.

\subsection{Existing Condition}

Active ventilation systems typically consist of ductwork connecting the tank, or tanks, to an exhauster system. The exhauster system normally consists of a moisture removal device, a heater, two HEPA filter banks in series, a fan, and a stack. The SSTs have breather filters that serve as inlet filters (WHC 1994b). It has been determined that all of the SST passive ventilation systems are adequate for steady state flammable gas conditions (WHC 1996a).

Through October 1991, tanks A-104 and A-105 were required to be actively ventilated to reduce waste temperature enough to maintain structural integrity. However, temperature trends have been analyzed and conclusions have been drawn that the tank temperatures have reached a steady-state below the established safety limit $\left[150^{\circ} \mathrm{C}\left(300^{\circ} \mathrm{F}\right)\right]$, with slight oscillations described to exist because of varying seasonal temperatures. Therefore, the active ventilation system (exhauster 296-P-17) was recommended to be permanently removed. Temperature trends continue to be monitored, and all tanks within A-farm are passively ventilated (WHC 1994c).

Tanks $\mathrm{C}-105$ and $\mathrm{C}-106$ are linked together for ventilation. The current active ventilation system is being modified by Project $W-320$. This project must meet the current authorization basis requirements for SST ventilation systems.

All of the SSTs in 241-SX Tank Farm are connected to the active ventilation system except $S X-113$ and $S X-115$ for a total of 13 tanks connected to the system. Seven of the tanks in the farm, SX-101 through SX-106 and SX-109, SX-107, SX-112 and SX-114 have been identified with flammable gas concerns (WHC 1996h). Additionally, seven of the tanks, SX-107 through $S X-112$, and $S X-114$, have been identified to have high heat loads (WHC 1996i). The active ventilation system in the 241-SX farm has exceeded its expected service life with components by as little as 17 years, and as much as 27 years (WHC 1994b). As a note, several hardware deficiencies exist upon review of other requirements and have been identified as follows: 1) filter housings are non-testable; and 2) there are several maintenance problems associated with the system. Additionally, the system has not proven its efficiency in removing organic vapors, hydrogen gas releases, or removing heat (WHC 1996k).

The compliance determination and status summary matrix for SSTs ventilation systems are provided in Appendix $A$ in tabular form and represents information gathered from numerous documents and interviews with Westinghouse Hanford Company personnel. 
HNF-SD-WM-ER-664, Rev. 0

\subsection{CONCLUSIONS AND RECOMMENDATIONS}

Based on the evaluation completed, both active and passive ventilation systems are acceptable for continued safe operation. However, a risk assessment should be performed on the SX-farm active ventilation system in the near future to further evaluate safety concerns.

Recommendations for system upgrades are provided below in section 5.4 .

Of the 149 SSTs, 15 are identified as requiring active ventilation systems. They are physically configured as follows: 1) C-farm: 1 system with 1 fan (tanks C-105 - C-106), and 2) 241-SX Farm: 1 system with 2 fans (tanks SX-101 -- SX-112 and SX-114). The remaining 134 tanks are required to be passively ventilated. Depending on configuration, equipment modifications may be required to be reviewed by the Hanford Flammable Gas Advisory Board.

\subsection{Ventilation Systems Meet Requirements}

A total of 134 tanks have been identified to maintain their present status. Salt Well Pumping is not allowed in 44 of the SSTs (FDH 1996b). Continued management of these tanks using the current management philosophy will adequately meet the TWRS mission and protect the health and safety of workers and general public.

\subsection{IS Criteria}

All 15 of the actively ventilated tanks require upgrades to meet the IS criteria for automatic pressure monitoring by TMACS (only tank $\mathrm{C}-106$ has pressure sensors hardwired to TMACS). Both actively ventilated systems (C-farm and $\mathrm{SX}$-farm) require upgrades for the stack radiation monitoring to be connected to TMACS. The details of IS criteria are described in the Controlled, Clean and Stable Design Requirements Document for Single-Shell Tanks (WHC 1996e).

\subsection{Operability of the Ventilation Equipment}

The ventilation equipment for the tanks in 241-SX-farm has been operating well beyond its useful life. Several problems have been identified in Tank Farm Restoration and Safe Operations Initial Assessment Report HVAC Systems as follows: 1) filter housings are non-testable; and 2) there are several maintenance problems associated with the system. Additionally, the system has not proven its efficiency in removing organic vapors, hydrogen gas releases, or removing heat (WHC 1996k).

Detailed results of evaluation for each SST are given in Appendix A under the "Comments" column and are summarized below.

\subsection{Recommendations for Continued Safe Operation of SSTs}

The following is a list of concise recommendations for continued safe operation of SSTs.

A. Continue to operate all passively ventilated tanks with maintenance schedules for safe operation. It is recommended that SSTs on the Flammable Gas or USQ Watch List be precisely monitored for gas release events and unusual events such as sudden increase of waste temperature. 
HNF-SD-WM-ER-664, Rev. 0

B. Perform a risk assessment on the 241-SX-farm active ventilation system. (Note: A process test utilizing data quality objectives was recently proposed to quantify and document the current peak waste temperatures and hydrogen levels on the actively ventilated SSTs in the 241-SX-farm. Results from this test along with a risk assessment would provide the authorization basis for determining if the system requires upgrade/reinstallation or removal of system. However, this process test was not funded for this fiscal year.)

C. Based on the risk assessment performed on the SX-farm active ventilation system, either replace the hardware or tum the system off and make sure that each of the those tanks meet the requirements for passive ventilation. Appendix $\mathrm{H}$ provides preliminary cost estimates for replacement of the hardware.

D. When a decision is made to go forward with interim stabilization of the SX-farm and Cfarm, pressure sensing instrumentation and radiation stack monitoring is required to be connected to TMACS in all of the 15 actively ventilated tanks (with the exception of tank C-106 which only requires TMACS connection of the radiation stack monitor).

E. Follow all requirements identified in the West/East Tank Farms Standing Order documents (FDH 1996a, FDH 1996b). Continue close watch for hydrogen and flammable gas releases. The performance of a ventilation system is now judged by it's efficiency to purge hydrogen and other flammable gases. 
HNF-SD-WM-ER-664, Rev. 0

\subsection{BIBLIOGRAPHY}

DOE/RL, 1990, Letter, M. Lawrence, DOE, Richland Operations, L. Duffy, U.S. Department of Energy, Headquarters, Flammable Gas Unreviewed Safety Question, dated May 14, 1990, U.S. Department of Energy, Richland Operations Office, Richland, Washington.

DOE/RL, 1994a, Hanfond Federal Facility Agreement and Consent Order, as amended, Washington State Department of Ecology, U. S. Environmental Protection Agency, and U. S. Department of Energy, Olympia, Washington.

DOE/RL, 1994b, Tank Waste Remediation System Functions and Requinements, DOE/RL-92-60, Rev 1, U. S. Department of Energy, Richland Operations Office, Richland, Washington.

FDH, 1996a, West Tank Farms Standing Order 96-34, Rev. 2, dated November 8, 1996, Fluor Daniel Hanford, Inc., Richland, Washington.

FDH, 1996b, East Tank Farms Standing Order 96-36, Rev. 2, dated November 8, 1996, Fluor Daniel Hanford, Inc., Richland, Washington.

NFPA, 1992, Recommended Practice for Classification of Class / Hazardous (Classified) Locations for Electrical Installations in Chemical Process Areas, 1992 Edition, National Fire Protection Association.

NFPA, 1993, National Electric Code, Articles 500 -- Hazardous (Classified) Locations and 501 -- Class I Locations, 1993 Edition, National Fire Protection Association.

NFPA, 1993, Recommended Safe Practices on Static Electricity, 1993 Edition, National Fire Protection Association.

RHO, 1980, Heat Transfer Analysis for In-Site Disposal of Nuclear Waste in Single- and Double-Shell Underground Storage Tanks, RHO-LD-171, Rockwell Hanford Operations, Richland, Washington.

RHO, 1985, Environmental Protection Manual, RHO-MA-139, Rockwell Hanford Operations, Richland, Washington.

WHC, 1990, A History of the 200 Area Tanks Farms, WHC-MR-0132, Westinghouse Hanford Company, Richland, Washington.

WHC, 1991, Safety Assessment for TV Camera and Lights, Installation, Operation and Removal in Tank 101-SY, WHC-SD-WM-SAD-005, Rev. 2, Westinghouse Hanford Company, Richland, Washington.

WHC, 1992, Summary of Single-Shell Waste Tank Stability, WHC-EP-0347, Supplement, Westinghouse Hanford Company, Richland, Washington.

WHC, 1993, Estimation of Heat Load in Waste Tanks Using Average Vapor Temperatures, WHC-EP-0709, Westinghouse Hanford Company, Richland, Washington. 
WHC, 1993, Revised Thermal History of Tank 241-C-106, WHC-SD-WM-ER-200, Westinghouse Hanford Company, Richland, Washington.

WHC, 1993, Thermal Analysis of Tank 241-C-105 in Support of Process Test, WHC-SD-WM-ER-178, Westinghouse Hanford Company, Richland, Washington.

WHC, 1994a, Single-Shell Tank Interim Operational Safety Requirements, WHC-SD-WM-OSR-005, Rev 1A, per ECN 604333 and ECN 165779, Westinghouse Hanford Company, Richland, Washington.

WHC, 1994b, An Engineering Review of Tank Farm Ventilation Systems, WHC-SD-WM-TI-612, Rev 0, Westinghouse Hanford Company, Richland, Washington.

WHC, 1994c, Recommendation on Need for an Exhauster on 241-A-105, WHC-SD-WM-RPT-075, Westinghouse Hanford Company, Richland, Washington.

WHC, 1994, Summary of Information on Flammable Gas Watch List Tanks, WHC-EP-0711, Westinghouse Hanford Company, Richland, Washington.

WHC, 1994, Construction, Maintentance, and Operational Activities Analysis Summaries, WHC-SD-WM-SARR-009, Westinghouse Hanford Company, Richland, Washington.

WHC, 1994, Tank Farm Ventilation Systems Operational Summaries, WHC-SD-WM-SARR-026, Rev 0, Westinghouse Hanford Company, Richland, Washington.

WHC, 1994, Ferrocyanide Safety Program: Assessment of the Possibility of Ferrocyanide Sludge Dryout, WHC-EP-0816, Westinghouse Hanford Company, Richland, Washington.

WHC, 1994, Single-Shell Tank Stabilization Record, WHC-SD-RE-TI-178, Rev 4, per ECNs $602442,171773,106864$, and 106858, Westinghouse Hanford Company, Richland, Washington.

WHC, 1995a, Hanford Site Tank Farm Facilities Interim Safety Basis, WHC-SD-WM-ISB-001, Rev $\mathrm{OH}$, Westinghouse Hanford Company, Richland, Washington.

WHC, 1995, Single-Shell Tank Isolation Safety Analysis Report, WHC-SD-WM-SAR-006, Rev 2, June 30, 1995, Westinghouse Hanford Company, Richland, Washington.

WHC,1995, Operating Specifications for Tank Farm Leak Detection and Single-Shell Tank Intrusion Detection, OSD-T-151-00031, Rev B-1, Westinghouse Hanford Company, Richland, Washington.

WHC, 1995, Strategy for Sampling Hanford Site Tank Wastes for Development of Disposal Technology, WHC-SD-WM-TA-154, Rev 1, Westinghouse Hanford Company, Richland, Washington.

WHC, 1995, Breather Filter Removal and Replacement, 6-TF-076, Rev 3, Change A, Westinghouse Hanford Company, Richland, Washington. 
WHC, 1995, Breather Filter In-Place Leak Test (Aerosol Test), 6-TF-157, Rev 0, Change B, Westinghouse Hanford Company, Richland, Washington.

WHC, 1995, Monitor/Change-Out Waste Storage Tank Breather Filters, TO-060-015, Rev E-0, , Westinghouse Hanford Company, Richland, Washington.

WHC, 1995, Internal Memo, from G. N. Hanson to W. E. Ross, Permanent Removal of 241-A105 Exhauster, \#95-060, dated September 18, 1995, Westinghouse Hanford Company, Richland, Washington.

WHC, 1996a, Flammable Gas/Slumy Growth Unreviewed Safety Question: Justification for Continued Operation for the Tank Farms at the Hanford Site, WHC-SD-WM-JCO-007, Rev 0, Westinghouse Hanford Company, Richland, WA.

WHC, 1996b, Tank Waste Remediation System Basis for Interim Operation, WHC-SD-WM-BIO-001, Rev E, Westinghouse Hanford Company, Richland, Washington.

WHC, 1996c, Tank Waste Remediation System Technical Safety Requirements, WHC-SD-WM-TSR-006, Rev E, Westinghouse Hanford Company, Richland, Washington.

WHC, 1996d, Tank Waste Remediation System Safety Structures, Systems, and Components: Requirements and Characteristics, WHC-SD-WM-RD-057, Rev 0, Richland, Washington.

WHC, 1996e, Controlled, Clean, and Stable Design Requirements Document for Single-Shell Tanks, WHC-SD-WM-DRD-009, Rev 1, Westinghouse Hanford Company, Richland, Washington.

WHC, 1996f, Evaluation of Hanford Tanks for Trapped Gas, Rev 1, WHC-SD-WM-ER-526, Westinghouse Hanford Company, Richland, Washington.

WHC, 1996g, Operating Specifications for Single-Shell Waste Storage Tanks, OSD-T-151-00013, Rev D-13, Westinghouse Hanford Company, Richland, Washington.

WHC, 1996h, Operating Specifications for Watch List Tanks, OSD-T-151-00030, Rev B-22, Westinghouse Hanford Company, Richland, Washington.

WHC, 1996i, Waste Tank Summary Report for Month Ending May 31, 1996, WHC-EP-0182-99, Westinghouse Hanford Company, Richland, Washington.

WHC, 1996j, Tank 241-C106 Waste Retrieval Sluicing Systems Operations Manual, WHCSD-W320-TI-004, Rev 0, Westinghouse Hanford Company, Richland, Washington.

WHC, 1996k, Tank Farm Restoration and Safe Operations Initial Assessment Report HVAC Systems, WHC-SD-W314-ES-022, Rev 0, Westinghouse Hanford Company, Richland, Washington.

WHC, 19961, A Safety Assessment for Rotary Mode Core Sampling in Flammable Gas Single Shell Tanks, Hanford Site, Richland, Washington, WHC-SD-WM-SAD-035, Rev. 0-a, Westinghouse Hanford Company, Richland, Washington. 
WHC, 1996m, A Safety Assessment for Salt Well Jet Pumping Operations in Tank 241-A-101: Hanford Site, Richland, Washington, WHC-SD-WM-SAD-036, Rev, 0, Westinghouse Hanford Company, Richland, Washington.

WHC, 1996, Electrical Classification Study for the Flammable Gas Watch List Tanks, WHC-SDWM-017, Rev 0, Westinghouse Hanford Company, Richland, Washington.

WHC 1996, Preliminary Design Requirements Document Tank Farm Upgrade System Project W-314, WHC-SD-W314-DRD-001, Rev 0, Westinghouse Hanford Company, Richland, Washington.

WHC, 1996, Equipment Design Guidance Document for Flammable Gas Waste Storage Tank New Equipment, WHC-SD-WM-DGS-005, Rev. 0, Westinghouse Hanford Company, Richland, Washington.

WHC, 1996, Expansion of Flammable Gas/Slurry Growth, USQ Evaluation TF-96-0433, Westinghouse Hanford Company, Richland, Washington.

WHC, 1996, Westinghouse Hanford Company Tank Waste Remediation System Division Milestone Description Sheet, Schedule ID: M4303, Rev, 0, ADS No: 1120-6, Tri-Party Agreement Milestone M-43-03, Westinghouse Hanford Company, Richland, Washington.

WHC, 1996, Tank Farm Safety and Authorization Basis Training, Course 351492, Student Text, Section III, Westinghouse Hanford Company Operations and Maintenance Programs, January 1996, Westinghouse Hanford Company, Richland Washington. 
HNF-SD-WM-ER-664, Rev. 0

\section{APPENDIX A}

\section{COMPLIANCE DETERMINATION AND STATUS SUMMARY FOR SINGLE-SHELL TANKS}




\section{HNF-SD-WM-ER-664, Rev. 0}

TABLE A-1. Compliance Determination and Status Summary for Single-Shell Tanks ${ }^{(1)}$.

NOTE: The footnotes that define each column are located on page A-17 and A-18.

\begin{tabular}{|c|c|c|c|c|c|c|c|c|c|c|c|c|}
\hline \multirow{2}{*}{$\begin{array}{l}\text { Tank ID } \\
\text { Number }\end{array}$} & \multirow{2}{*}{$\begin{array}{l}\text { Watch List }^{(2)} \\
\text { Status } \\
\text { (Justification) }\end{array}$} & \multirow{2}{*}{$\begin{array}{l}\text { Type of }{ }^{(3)} \\
\text { Vent } \\
\text { System } \\
\text { (Active or } \\
\text { Passive) }\end{array}$} & \multirow{2}{*}{$\begin{array}{l}\text { Stabilization } \\
\text { (4) Status }\end{array}$} & \multirow{2}{*}{$\begin{array}{l}\text { Vent }{ }^{(5)} \\
\text { Fitter } \\
\text { Type }\end{array}$} & \multicolumn{7}{|c|}{ Requirements ${ }^{\left({ }^{()}\right.}$} & \multirow[t]{2}{*}{ Comments } \\
\hline & & & & & $10 S R^{(6 A)}$ & $\mathrm{S} / \mathrm{O}^{(68)}$ & $\operatorname{ssc}^{(6 C)}$ & $T S R^{(6 D)}$ & \begin{tabular}{|l} 
IS(6E) \\
(for vent. \\
only)
\end{tabular} & $\begin{array}{l}\text { OSD- } \\
13^{6 \%}\end{array}$ & $\begin{array}{l}\text { OSD- } \\
30^{(6 G)}\end{array}$ & \\
\hline A-101 & $\begin{array}{l}\text { Hydrogent } \\
\text { Organics }\end{array}$ & $p$ & $\mathrm{Pl}$ & $\begin{array}{l}\text { Open } \\
\text { Face }\end{array}$ & $Y$ & $2 y$ & Y & N/A & N/A & $Y$ & Y & $\begin{array}{l}\text { Continue to maintain present } \\
\text { tatus. }\end{array}$ \\
\hline A-102 & Non-Watch list & $P$ & $|S / P|$ & $\begin{array}{l}\text { Open } \\
\text { Face }\end{array}$ & $Y$ & $3, Y$ & $Y$ & N/A & N/A & Y & $\mathrm{Y}$ & $\begin{array}{l}\text { Continue to maintain present } \\
\text { status. }\end{array}$ \\
\hline A-103 & Flam Gas USQ & $P$ & ISAP & $\begin{array}{l}\text { Open } \\
\text { Face }\end{array}$ & $Y$ & $2 Y$ & $y$ & NIA & N/A & $Y$ & $Y$ & $\begin{array}{l}\text { Continue to maintain present } \\
\text { tatus. }\end{array}$ \\
\hline A-104 & Non-Watch list & $P$ & $I S / P$ & $\begin{array}{l}\text { Open } \\
\text { Face }\end{array}$ & $Y$ & $3, Y$ & $Y$ & N/A & $N$ & 4,14 & $Y$ & $\begin{array}{l}\text { Continue to maintain present } \\
\text { status. } \\
\text { Note: If this system is deemed } \\
\text { o be active again then } \\
\text { jpgrades will be necessary. }\end{array}$ \\
\hline$A-105$ & $\begin{array}{l}\text { Non-Watch list } \\
\text { Damaged Tank) }\end{array}$ & $P$ & IS/P & none & Y & $3, Y$ & Y & N/A & $\mathrm{N}$ & 4,14 & $\gamma$ & $\begin{array}{l}\text { Continue to maintain present } \\
\text { status. } \\
\text { Note: If this system is deemed } \\
\text { o be active again then } \\
\text { upgrades will be necessary. }\end{array}$ \\
\hline A-106 & Non-Watch list & $P$ & $I S / P$ & None & $Y$ & $3, Y$ & Y & N/A & $N$ & 4,14 & $Y$ & $\begin{array}{l}\text { Continue to maintain present } \\
\text { status. } \\
\text { Note: If this system is deemed } \\
\text { o be active again then } \\
\text { upgrades will be necessary. }\end{array}$ \\
\hline$A x-101$ & Hydrogen & $P$ & IP & $\begin{array}{l}\text { Open } \\
\text { Face }\end{array}$ & Y & $3 y$ & $Y$ & N/A & N/A & $Y$ & $Y$ & $\begin{array}{l}\text { Contriue to maintain present } \\
\text { ftatus }\end{array}$ \\
\hline$A x-102$ & Organics: & $P$ & ISAP & $\begin{array}{l}\text { Open } \\
\text { Faç }\end{array}$ & $Y$ & $3 Y$ & $Y$ & NIA & $N / A$ & $Y$ & $Y$ & $\begin{array}{l}\text { Conbinue to maintain present } \\
\text { Ptatus }\end{array}$ \\
\hline
\end{tabular}


HNF-SD-WM-ER-664, Rev. 0

\begin{tabular}{|c|c|c|c|c|c|c|c|c|c|c|c|c|}
\hline \multirow{2}{*}{$\begin{array}{l}\text { Tank ID } \\
\text { Number }\end{array}$} & \multirow{2}{*}{$\begin{array}{l}\text { Watch List }^{(2)} \\
\text { Status } \\
\text { (Justification) }\end{array}$} & \multirow{2}{*}{$\begin{array}{l}\text { Type of }{ }^{(3)} \\
\text { Vent } \\
\text { System } \\
\text { (Active or } \\
\text { Passive) }\end{array}$} & \multirow{2}{*}{$\begin{array}{l}\text { Stabilization } \\
\text { (4) Status }\end{array}$} & \multirow{2}{*}{$\begin{array}{l}\text { Vent }^{(5)} \\
\text { Filter } \\
\text { Type }\end{array}$} & \multicolumn{7}{|c|}{ Requirements $^{(\theta)}$} & \multirow[t]{2}{*}{ Comments } \\
\hline & & & & & $\operatorname{los} R^{(6 A)}$ & $\mathrm{S} / \mathrm{O}^{(6 \mathrm{~B})}$ & $\operatorname{SSC}^{(6 C)}$ & $T S R^{(6 D)}$ & $\begin{array}{l}\text { IS }(6 E) \\
\text { (for vent. } \\
\text { only) }\end{array}$ & $\begin{array}{l}\text { OSD- } \\
13^{(6 F)}\end{array}$ & $\begin{array}{l}\text { OSD- } \\
30^{(6 G)}\end{array}$ & \\
\hline$A x-103$ & Hydrogen & $P$ & ISAP & $\begin{array}{l}\text { Open } \\
\text { Face }\end{array}$ & $y$ & $3 Y$ & $Y$ & NIA & $N / A$ & $\mathrm{Y}$ & $Y$ & Continue to maintain present \\
\hline$A X-104$ & Non-Watch list & $P$ & IS $/ \mathrm{P}$ & $\begin{array}{l}\text { Open } \\
\text { Face }\end{array}$ & $Y$ & $3, Y$ & $Y$ & $\mathrm{~N} / \mathrm{A}$ & N/A & $Y$ & $Y$ & $\begin{array}{l}\text { Continue to maintain present } \\
\text { status. }\end{array}$ \\
\hline B-101 & Non-Watch list & $P$ & IS/IP & $\begin{array}{l}\text { Open } \\
\text { Face }\end{array}$ & $Y$ & $3, Y$ & $Y$ & N/A & N/A & $Y$ & $Y$ & $\begin{array}{l}\text { Continue to maintain present } \\
\text { status. }\end{array}$ \\
\hline B-102 & Non-Watch list & $P$ & IS/P & $\begin{array}{c}\text { G-1 } \\
\text { Housing }\end{array}$ & $Y$ & $3, Y$ & $Y$ & $N / A$ & N/A & $\mathrm{Y}$ & $Y$ & $\begin{array}{l}\text { Continue to maintain present } \\
\text { status. }\end{array}$ \\
\hline B-103 & Organics & $P$ & ISAP & $\begin{array}{c}\text { G1 } \\
\text { Housing }\end{array}$ & $Y$ & $3, Y$ & $Y$ & NIA & N/A & $Y$ & $Y$ & $\begin{array}{l}\text { Continute to malntain present } \\
\text { flatus }\end{array}$ \\
\hline B-104 & Non-Watch list & $P$ & IS/IP & $\begin{array}{c}\text { G-1 } \\
\text { Housing }\end{array}$ & $Y$ & $3, Y$ & $Y$ & N/A & N/A & $Y$ & $Y$ & $\begin{array}{l}\text { Continue to maintain present } \\
\text { status. }\end{array}$ \\
\hline B-105 & Non-Watch list & $P$ & IS/P & $\begin{array}{c}\text { G-1 } \\
\text { Housing }\end{array}$ & $Y$ & $3, Y$ & $Y$ & $N / A$ & N/A & $Y$ & $Y$ & $\begin{array}{l}\text { Continue to maintain present } \\
\text { status. }\end{array}$ \\
\hline B-106 & Non-Watch list & $P$ & IS/P & $\begin{array}{c}\text { G-1 } \\
\text { Housing }\end{array}$ & $Y$ & $3, Y$ & $Y$ & $\mathrm{~N} / \mathrm{A}$ & N/A & $Y$ & $Y$ & $\begin{array}{l}\text { Continue to maintain present } \\
\text { tatus. }\end{array}$ \\
\hline B-107 & Non-Watch list & $P$ & $I S / P$ & $\begin{array}{l}\text { Open } \\
\text { Face }\end{array}$ & $Y$ & $3, Y$ & $Y$ & N/A & N/A & $Y$ & $Y$ & $\begin{array}{l}\text { Continue to maintain present } \\
\text { status. }\end{array}$ \\
\hline $8-108$ & Non-Watch list & $P$ & IS/IP & $\begin{array}{c}\text { G-1 } \\
\text { Housing }\end{array}$ & $Y$ & $3, Y$ & $Y$ & N/A & N/A & $Y$ & $Y$ & $\begin{array}{l}\text { Continue to maintain present } \\
\text { status. }\end{array}$ \\
\hline B-109 & Non-Watch list & $P$ & IS $/ \mathrm{P}$ & $\begin{array}{c}\text { G-1 } \\
\text { Housing }\end{array}$ & $Y$ & $3, Y$ & $Y$ & N/A & N/A & $Y$ & $Y$ & $\begin{array}{l}\text { Continue to maintain present } \\
\text { status. }\end{array}$ \\
\hline B-110 & Non-Watch list & $P$ & IS/P & $\begin{array}{l}\text { Open } \\
\text { Face }\end{array}$ & $Y$ & $3, Y$ & $Y$ & N/A & N/A & $Y$ & $Y$ & $\begin{array}{l}\text { Continue to maintain present } \\
\text { status. }\end{array}$ \\
\hline B-111 & Non-Watch list & $P$ & IS/P & $\begin{array}{c}\text { G-1 } \\
\text { Housing }\end{array}$ & $Y$ & $3, Y$ & $Y$ & N/A & N/A & $Y$ & $Y$ & $\begin{array}{l}\text { Continue to maintain present } \\
\text { status. }\end{array}$ \\
\hline
\end{tabular}


HNF-SD-WM-ER-664, Rev. 0

\begin{tabular}{|c|c|c|c|c|c|c|c|c|c|c|c|c|}
\hline \multirow{2}{*}{$\begin{array}{l}\text { Tank 1D } \\
\text { Number }\end{array}$} & \multirow{2}{*}{$\begin{array}{l}\text { Watch List } \\
\text { Status } \\
\text { (Justification) }\end{array}$} & \multirow{2}{*}{$\begin{array}{l}\text { Type of }{ }^{(3)} \\
\text { Vent } \\
\text { System } \\
\text { (Active or } \\
\text { Passive) }\end{array}$} & \multirow{2}{*}{$\begin{array}{l}\text { Stabilization } \\
\text { (4) }_{\text {Status }}\end{array}$} & \multirow{2}{*}{$\begin{array}{l}\text { Vent }^{(5)} \\
\text { Filter } \\
\text { Type }\end{array}$} & \multicolumn{7}{|c|}{ Requirements ${ }^{(6)}$} & \multirow[t]{2}{*}{ Comments } \\
\hline & & & & & $1 O S R^{(6 A)}$ & $S / O^{(6 B)}$ & $\operatorname{ssc}^{(6 C)}$ & $\mathrm{TSR}^{(6 \mathrm{D})}$ & $\begin{array}{l}\text { IS(6E) } \\
\text { (for vent. } \\
\text { only) }\end{array}$ & $\begin{array}{l}\text { OSD- } \\
13^{(6 F)}\end{array}$ & $\begin{array}{l}\text { OSD- } \\
30^{(6 G)}\end{array}$ & \\
\hline B-112 & Non-Watch list & $P$ & $\mathrm{IS} / \mathrm{P}$ & $\begin{array}{c}\text { G-1 } \\
\text { Housing }\end{array}$ & $Y$ & $3, Y$ & $Y$ & N/A & N/A & $Y$ & $Y$ & $\begin{array}{l}\text { Continue to maintain present } \\
\text { status. }\end{array}$ \\
\hline $\mathrm{B}-201$ & Flam, Gas USQ & $P$ & ISAP & Open & Y & $2 y$ & $\mathrm{Y}$ & N/A & N/A & Y & $y$ & $\begin{array}{l}\text { Contnue to maintain present } \\
\text { tatus. }\end{array}$ \\
\hline $\mathrm{B}-202$ & Flam. Gas USQ & P & ISAP: & Gousing & $Y$ & $2 Y$ & $Y$ & $N / A$ & $\mathrm{~N} / \mathrm{A}$ & Y & $y$ & $\begin{array}{l}\text { Continute to maintain present } \\
\text { Gtatus }\end{array}$ \\
\hline$B-203$ & Non-Watch list & $P$ & ISAP & $\begin{array}{c}\text { G-1 } \\
\text { Housing }\end{array}$ & $Y$ & $3, Y$ & $Y$ & N/A & N/A & $Y$ & $Y$ & $\begin{array}{l}\text { Continue to maintain present } \\
\text { status. }\end{array}$ \\
\hline B-204 & Non-Watch list & $P$ & IS/P & $\begin{array}{c}\text { G-1 } \\
\text { Housing }\end{array}$ & $Y$ & $3, Y$ & $\gamma$ & N/A & N/A & $Y$ & $Y$ & $\begin{array}{l}\text { Continue to maintain present } \\
\text { status. }\end{array}$ \\
\hline$B X-101$ & Non-Watch list & $P$ & IS $/ \mathrm{P}$ & $\begin{array}{l}\text { Open } \\
\text { Face }\end{array}$ & $Y$ & $3, Y$ & $Y$ & N/A & N/A & $Y$ & $Y$ & $\begin{array}{l}\text { Continue to maintain present } \\
\text { status. }\end{array}$ \\
\hline$B X-102$ & Non-Watch list & $P$ & IS $/ \mathrm{P}$ & $\begin{array}{l}\text { Open } \\
\text { Face }\end{array}$ & $Y$ & $3, Y$ & $Y$ & N/A & N/A & $Y$ & $Y$ & $\begin{array}{l}\text { Continue to maintain present } \\
\text { status. }\end{array}$ \\
\hline $\mathrm{BX}-103$ & Non-Watch list & $\mathrm{P}$ & IS/P & $\begin{array}{c}\text { G-1 } \\
\text { Housing }\end{array}$ & $Y$ & $3, Y$ & $Y$ & $N / A$ & N/A & $Y$ & $\mathrm{Y}$ & $\begin{array}{l}\text { Continue to maintain present } \\
\text { status. }\end{array}$ \\
\hline$B X-104$ & Non-Watch list & $\mathbf{P}$ & IS/P & $\begin{array}{c}\text { G-1 } \\
\text { Housing }\end{array}$ & Y & $3, Y$ & $\mathrm{Y}$ & N/A & N/A & $Y$ & $Y$ & $\begin{array}{l}\text { Continue to maintain present } \\
\text { status. }\end{array}$ \\
\hline BX-105 & Non-Watch list & $P$ & IS $/ P$ & $\begin{array}{c}\text { G-1 } \\
\text { Housing }\end{array}$ & Y & $3, Y$ & $Y$ & N/A & N/A & $Y$ & $Y$ & $\begin{array}{l}\text { Continue to maintain present } \\
\text { status. }\end{array}$ \\
\hline$B \times-106$ & Non-Watch list & $P$ & IS/PI & $\begin{array}{c}\text { G-1 } \\
\text { Housing }\end{array}$ & Y & $3, Y$ & $Y$ & N/A & $N / A$ & $Y$ & Y & $\begin{array}{l}\text { Continue to maintain present } \\
\text { status. }\end{array}$ \\
\hline$B \times-107$ & Flam Gas USA & $P$ & ISPI & G-1 & $y$ & $2 Y$ & $\mathrm{Y}$ & N/A & NIA & $Y$ & $y$ & $\begin{array}{l}\text { Continte to maintain present } \\
\text { Ptatus }\end{array}$ \\
\hline$B X-108$ & Non-Watch list & $P$ & IS $/ P$ & $\begin{array}{l}\text { Open } \\
\text { Face }\end{array}$ & $Y$ & $3, Y$ & $Y$ & N/A & N/A & Y & $Y$ & $\begin{array}{l}\text { Continue to maintain present } \\
\text { status. }\end{array}$ \\
\hline
\end{tabular}


HNF-SD-WM-ER-664, Rev. 0

\begin{tabular}{|c|c|c|c|c|c|c|c|c|c|c|c|c|}
\hline \multirow{2}{*}{$\begin{array}{l}\text { Tank ID } \\
\text { Number }\end{array}$} & \multirow{2}{*}{$\begin{array}{l}\text { Watch List }^{(2)} \\
\text { Status } \\
\text { (Justification) }\end{array}$} & \multirow{2}{*}{$\begin{array}{l}\text { Type of } \\
\text { Vent } \\
\text { System } \\
\text { (Active or } \\
\text { Passive) }\end{array}$} & \multirow{2}{*}{$\begin{array}{l}\text { Stabilization } \\
{ }^{(4)} \text { Status }\end{array}$} & \multirow{2}{*}{$\begin{array}{l}\text { Vent }^{(5)} \\
\text { Fitter } \\
\text { Type }\end{array}$} & \multicolumn{7}{|c|}{ Requirements ${ }^{(6)}$} & \multirow[t]{2}{*}{ Comments } \\
\hline & & & & & $\operatorname{OSS} R^{(6 \mathrm{~A})}$ & $S / O^{(6 B)}$ & $\operatorname{SSC}^{(6 C)}$ & $\mathrm{TSR}^{(60)}$ & $\begin{array}{l}\text { IS(6e) } \\
\text { (for vent. } \\
\text { onty) }\end{array}$ & $\underset{13^{(6 F)}}{\operatorname{OSP}}$ & $\begin{array}{l}\text { OSD- } \\
30^{(6 G)}\end{array}$ & \\
\hline$B \times-109$ & Non-Watch list & $P$ & $\mid \mathrm{S} / \mathrm{PI}$ & $\begin{array}{c}\text { G-1 } \\
\text { Housing }\end{array}$ & $Y$ & $3, Y$ & $Y$ & N/A & N/A & $Y$ & $Y$ & $\begin{array}{l}\text { Continue to maintain present } \\
\text { status. }\end{array}$ \\
\hline$B X-110$ & Non-Watch list & $P$ & $|\mathrm{~S} / \mathrm{P}|$ & $\begin{array}{l}\text { Open } \\
\text { Face }\end{array}$ & $Y$ & $3, Y$ & $Y$ & N/A & N/A & $Y$ & $Y$ & $\begin{array}{l}\text { Continue to maintain present } \\
\text { status. }\end{array}$ \\
\hline$B X-111$ & Non-Watch list & $P$ & $\mid \mathrm{S} / \mathrm{PI}$ & $\begin{array}{c}\text { G-1 } \\
\text { Housing }\end{array}$ & $Y$ & $3, Y$ & $Y$ & N/A & N/A & $Y$ & $Y$ & $\begin{array}{l}\text { Continue to maintain present } \\
\text { status. }\end{array}$ \\
\hline$B X-112$ & Non-Watch list & $P$ & $|\mathrm{~S} / \mathrm{P}|$ & $\begin{array}{c}\text { G-1 } \\
\text { Housing }\end{array}$ & $Y$ & $3, Y$ & $Y$ & N/A & N/A & $Y$ & $Y$ & $\begin{array}{l}\text { Continue to maintain present } \\
\text { status. }\end{array}$ \\
\hline$B Y-101$ & Flam Gas USQ & $P$ & ISAP & $\begin{array}{c}\text { Q-1 } \\
\text { Housing }\end{array}$ & $Y$ & $2, Y$ & $Y$ & N/A & NAA & $Y$ & $Y$ & $\begin{array}{l}\text { Continue to maintan present } \\
\text { tatus }\end{array}$ \\
\hline $\mathrm{BY}-102$ & Flam Gas USQ & $P$ & ISFI: & Open & $Y$ & $2, Y$ & $\Upsilon$ & N/A & NVA & $Y$ & $Y$ & $\begin{array}{l}\text { Continue to maintain present } \\
\text { ftatus }\end{array}$ \\
\hline $\mathrm{BY}-103$ & $\begin{array}{l}\text { FecN and } \\
\text { Flam, Gas USQ }\end{array}$ & $P$ & 91 & Open & $y$ & $2, Y$ & $\mathbf{Y}$ & NIA & $\mathrm{N} / \mathrm{A}$ & $Y$ & $Y$ & $\begin{array}{l}\text { Continue to maintain present } \\
\text { Btatus }\end{array}$ \\
\hline$B Y-104$ & $\mathrm{FeCN}$ & $\mathbf{P}$ & ISAP & Gousing & $y$ & $3, Y$ & $y$ & N/A & $N / A$ & $Y$ & $\mathbf{Y}$ & $\begin{array}{l}\text { Continue to maintain present } \\
\text { Ptatus }\end{array}$ \\
\hline $\mathrm{BY}-105$ & $\begin{array}{l}\text { FeCN and } \\
\text { Flam Gas USQ }\end{array}$ & $P$ & PI & Open: & $y$ & $2, Y$ & $Y$ & N/A & $N A$ & $y$ & Y & Continute to maintain present \\
\hline $\mathrm{BY}-106$ & $\begin{array}{l}\text { FeCN and } \\
\text { Flam Gas USQ }\end{array}$ & $\mathbf{P}$ & PI: & Open & $y$ & $2 Y$ & $Y$ & N/A & NUA & $Y$ & $y$ & Contunue to maintan present \\
\hline$B Y-107$ & $F_{\odot C N}$ & $\mathbf{P}$ & ISAP & Fapen & $Y$ & $3, Y$ & $Y$ & N/A & NA & $\mathrm{Y}$ & $Y$ & $\begin{array}{l}\text { Continue to maintain present } \\
\text { ftatus. }\end{array}$ \\
\hline $\mathrm{BY}-108$ & FeCN & $P$ & ISAP & Open & 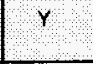 & $3 \mathrm{Y}$ & $\mathbf{Y}$ & N/A & N/A & $y$ & $Y$ & Continute to maintan present \\
\hline$B Y-109$ & Flam Gas USQ & $\mathbf{P}$ & PI & G1 & $y$ & $2 Y$ & $\mathbf{Y}$ & N/A & $\mathrm{N} / \mathrm{A}$ & $Y$ & $Y$ & $\begin{array}{l}\text { Continue to maintain present } \\
\text { tatus }\end{array}$ \\
\hline
\end{tabular}


HNF-SD-WM-ER-664, Rev. 0

\begin{tabular}{|c|c|c|c|c|c|c|c|c|c|c|c|c|}
\hline \multirow{2}{*}{$\begin{array}{l}\text { Tank ID } \\
\text { Number }\end{array}$} & \multirow{2}{*}{$\begin{array}{l}\text { Watch List }^{(2)} \\
\text { Status } \\
\text { (Justification) }\end{array}$} & \multirow{2}{*}{$\begin{array}{l}\text { Type of } \text { f }^{(3)} \\
\text { Vent } \\
\text { System } \\
\text { (Active or } \\
\text { Passive) }\end{array}$} & \multirow{2}{*}{$\begin{array}{l}\text { Stabilization } \\
{ }_{(4)} \text { Status }\end{array}$} & \multirow{2}{*}{\begin{tabular}{|l} 
Vent $^{(5)}$ \\
Fitter \\
Type
\end{tabular}} & \multicolumn{7}{|c|}{ Requirements ${ }^{(6)}$} & \multirow[t]{2}{*}{ Comments } \\
\hline & & & & & $\mathrm{OSR}^{(6 \mathrm{~A})}$ & $S 10^{(68)}$ & $\operatorname{ssc}^{(6 C)}$ & $\operatorname{TSR}^{(6 \mathrm{D})}$ & \begin{tabular}{|c|} 
IS(6E) \\
(for vent. \\
only) \\
\end{tabular} & $\begin{array}{l}\text { OSD- } \\
13^{(6)}\end{array}$ & $\begin{array}{l}\text { OSD- } \\
30^{(6 G)}\end{array}$ & \\
\hline BY-110 & $\mathrm{FeCN}$ & $P$ & ISAP & Housing & $Y$ & $3, Y$ & Y & N/A & N/A & Y & $Y$ & $\begin{array}{l}\text { Continue to maintain present } \\
\text { ftatus. }\end{array}$ \\
\hline$B Y-111$ & $\mathrm{FeCN}$ & $P$ & ISRP & Gousing & $Y$ & $3, Y$ & $\checkmark$ & N/A & N/A & Y & Y & $\begin{array}{l}\text { Continue to maintain present } \\
\text { tatus }\end{array}$ \\
\hline BY -112 & FeCN & $P$ & ISNP & Housing & $Y$ & $3 Y$ & $Y$ & N/A & N/A & Y & Y & $\begin{array}{l}\text { Continue to maintain present } \\
\text { tatus }\end{array}$ \\
\hline$C-101$ & Non-Watch list & $P$ & $I S / P$ & $\begin{array}{l}\text { Open } \\
\text { Face }\end{array}$ & Y & $3, Y$ & Y & N/A & N/A & Y & Y & $\begin{array}{l}\text { Continue to maintain present } \\
\text { status. }\end{array}$ \\
\hline $\mathrm{C}-102$ & Organics & $\mathrm{P}$ & ISPI: & $\begin{array}{l}\text { Open } \\
\text { Face }\end{array}$ & $Y$ & $3, Y$ & $r$ & NIA & N/A & $Y$ & Y & $\begin{array}{l}\text { Continue to maintain present } \\
\text { fatus }\end{array}$ \\
\hline $\mathrm{C}-103$ & Organics & $\mathbf{P}$ & PI & $\begin{array}{l}\text { G-1 } \\
\text { Housing }\end{array}$ & $Y$ & $3, Y$ & $r$ & NA & N/A & Y & Y & $\begin{array}{l}\text { Continue to maintain present } \\
\text { tatus. }\end{array}$ \\
\hline C. 104 & Flam Gas USQ & $P$ & ISAP & Open & $Y$ & $2, Y$ & $Y$ & N/A & $N$ & Y & $Y$ & $\begin{array}{l}\text { Continue to maintain present } \\
\text { ftatus. }\end{array}$ \\
\hline C-105 & Non-Watch list & A & IS/PI & N/A & Y & $3, Y$ & $Y$ & $Y$ & $\mathbf{N}$ & Y & Y & $\begin{array}{l}\text { Need to comply with iS } \\
\text { ventilation criteria for monitoring } \\
\text { emperature, pressure, and } \\
\text { stack radiation } \\
\text { levels. } \\
\text { Note: Project } W-320 \text { is } \\
\text { providing its own S/O compliant } \\
\text { ventilation system. }\end{array}$ \\
\hline $\mathrm{c}-106$ & High Heat & A & PI & N/A & $Y$ & $3, Y$ & Y & Y & $\mathrm{N}$ & $Y$ & $Y$ & 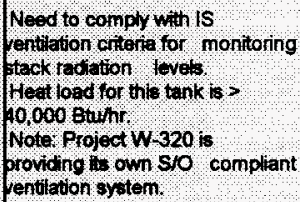 \\
\hline
\end{tabular}


HNF-SD-WM-ER-664, Rev. 0

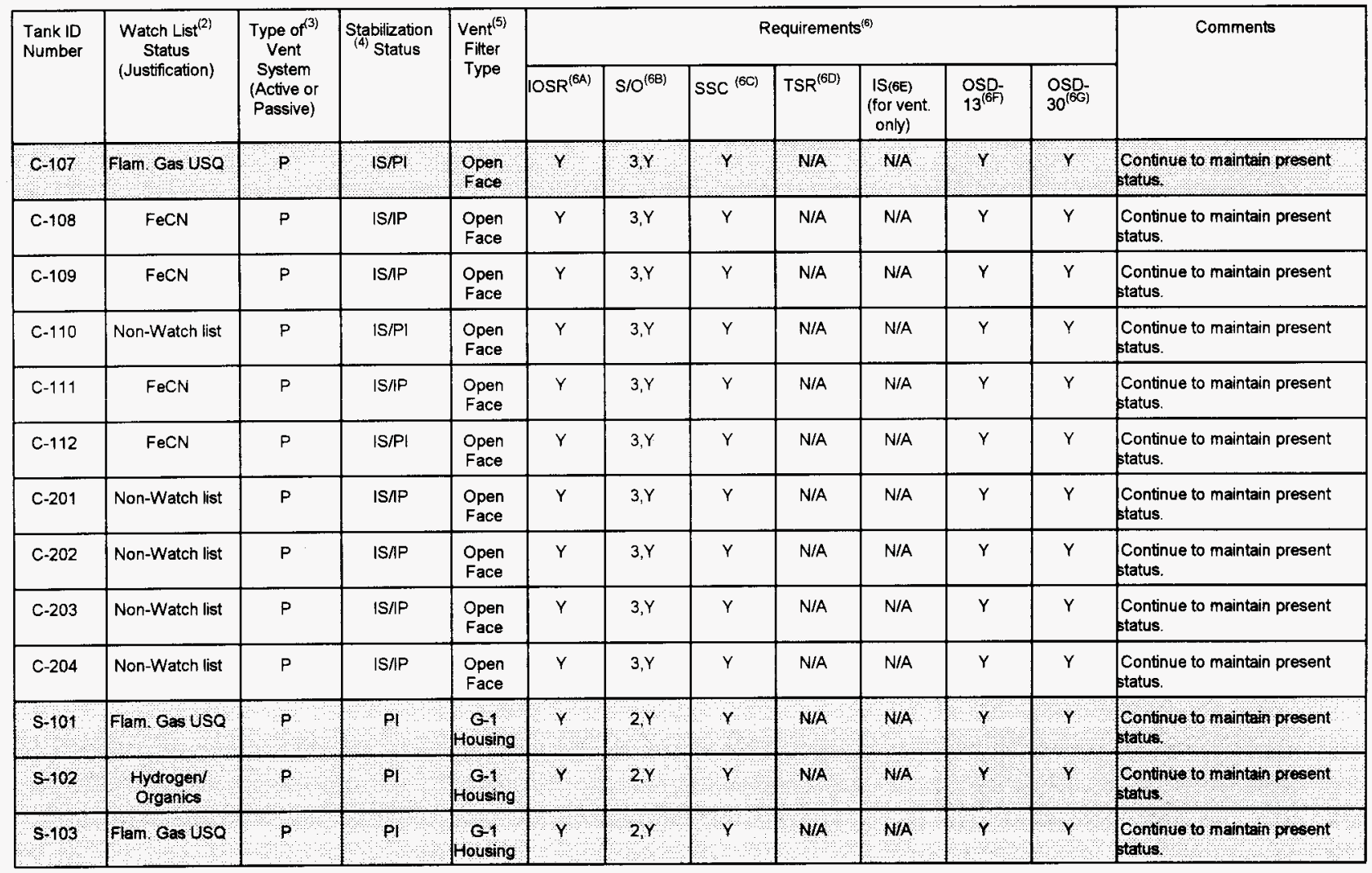


HNF-SD-WM-ER-664, Rev. 0

\begin{tabular}{|c|c|c|c|c|c|c|c|c|c|c|c|c|}
\hline \multirow{2}{*}{$\begin{array}{l}\text { Tank ID } \\
\text { Number }\end{array}$} & \multirow{2}{*}{$\begin{array}{l}\text { Watch List }^{(2)} \\
\text { Status } \\
\text { (Justification) }\end{array}$} & \multirow{2}{*}{$\begin{array}{l}\text { Type of }{ }^{(3)} \\
\text { Vent } \\
\text { System } \\
\text { (Active or } \\
\text { Passive) }\end{array}$} & \multirow{2}{*}{$\begin{array}{l}\text { Stabilization } \\
{ }^{(4)} \text { Status }\end{array}$} & \multirow{2}{*}{$\begin{array}{l}\text { Vent }^{(5)} \\
\text { Filter } \\
\text { Type }\end{array}$} & \multicolumn{7}{|c|}{ Requirements ${ }^{(\theta)}$} & \multirow[t]{2}{*}{ Comments } \\
\hline & & & & & $\operatorname{IOSR}^{(6 A)}$ & $\mathrm{S} / \mathrm{O}^{(6 \mathrm{~B})}$ & $\mathrm{SSC}^{(6 \mathrm{C})}$ & $\mathrm{TSR}^{(60)}$ & $\begin{array}{l}\text { IS(6E) } \\
\text { (for vent. } \\
\text { only) }\end{array}$ & $\begin{array}{l}\text { OSD- } \\
13^{(6 F)}\end{array}$ & $\begin{array}{l}\text { OSD- } \\
30^{(66)}\end{array}$ & \\
\hline S-104 & Non-Watch list & $P$ & $1 S / P$ & $\begin{array}{l}\text { Open } \\
\text { Face }\end{array}$ & $Y$ & $3, Y$ & $Y$ & N/A & N/A & $Y$ & $Y$ & $\begin{array}{l}\text { Continue to maintain present } \\
\text { status. }\end{array}$ \\
\hline $\mathrm{S}-105$ & Ftam, Gas $15 \mathrm{Q}$ & $p$ & $\mathrm{~s} / \mathrm{P}$ & Gousing & $y$ & $2 y$ & $Y$ & N/A & N/A & $y$ & Y & $\begin{array}{l}\text { Contrnte to maintain present } \\
\text { tatus. }\end{array}$ \\
\hline S-106 & Flam Gas USQ & $p$ & $\mathrm{Pl}$ & $\begin{array}{l}\text { G-1 } \\
\text { Housing }\end{array}$ & $Y$ & $2 Y$ & $y$ & $\mathrm{~N} / \mathrm{A}$ & NHA & $Y$ & $Y$ & $\begin{array}{l}\text { Conthnue to maintain present } \\
\text { ftatus }\end{array}$ \\
\hline S-107 & Flam. Gas USQ & $P$ & PI & $\begin{array}{l}\mathrm{G}-1 \\
\text { Housing }\end{array}$ & $Y$ & $2, Y$ & $Y$ & NIA & $\mathrm{N} / \mathrm{A}$ & $Y$ & $Y$ & $\begin{array}{l}\text { Contunue to maintain present: } \\
\text { ptatus. }\end{array}$ \\
\hline S-108 & Non-Watch list & $P$ & PI & $\begin{array}{c}\text { G-1 } \\
\text { Housing }\end{array}$ & $Y$ & $3, Y$ & $Y$ & N/A & $N / A$ & $Y$ & $Y$ & $\begin{array}{l}\text { Continue to maintain present } \\
\text { status. }\end{array}$ \\
\hline $5-109$ & Flam Gas USQ & $P$ & $\mathrm{Pl}$ & $\begin{array}{c}\text { G-1 } \\
\text { Housing }\end{array}$ & $\mathrm{Y}$ & $2, \mathrm{Y}$ & $Y$ & N/A & N/A & $\mathrm{y}$ & $\gamma$ & $\begin{array}{l}\text { Continue to maintain present } \\
\text { ftatus }\end{array}$ \\
\hline$S-110$ & Non-Watch list & $P$ & PI & $\begin{array}{c}\text { G-1 } \\
\text { Housing }\end{array}$ & $Y$ & $3, Y$ & $Y$ & N/A & N/A & $Y$ & $Y$ & $\begin{array}{l}\text { Continue to maintain present } \\
\text { status. }\end{array}$ \\
\hline$s-111$ & $\begin{array}{l}\text { Hydrogen/ } \\
\text { Organics }\end{array}$ & $p$ & PI: & Housing & $y$ & $2 y$ & $\gamma$ & N/A & $\mathrm{N} / \mathrm{A}$ & $\mathrm{Y}$ & $Y$ & $\begin{array}{l}\text { Continue to mantein present } \\
\text { tatus }\end{array}$ \\
\hline$\$-112$ & Hydrogen & $P$ & $\mathrm{PI}$ & Housing & $Y$ & $2 Y$ & $\gamma$ & N/A & $\mathrm{N} / \mathrm{A}$ & $Y$ & $\mathbf{Y}$ & $\begin{array}{l}\text { Continte to maintain present } \\
\text { tattis }\end{array}$ \\
\hline$S \times 101$ & Hydrogen & A & 9 & N/A & 3 & $2 Y$ & $Y$ & $y$ & $N$ & $y$ & $y$ & $\begin{array}{l}\text { Risk assessment should be } \\
\text { performed } \\
\text { Necd to comply with is } \\
\text { Jentiation critena for } \\
\text { monitoring pressure and stack } \\
\text { adiation levels }\end{array}$ \\
\hline
\end{tabular}


HNF-SD-WM-ER-664, Rev. 0

\begin{tabular}{|c|c|c|c|c|c|c|c|c|c|c|c|c|}
\hline \multirow{2}{*}{$\begin{array}{l}\text { Tank ID } \\
\text { Number }\end{array}$} & \multirow{2}{*}{$\begin{array}{l}\text { Watch List } \\
\text { Status } \\
\text { (Justification) }\end{array}$} & \multirow{2}{*}{$\begin{array}{l}\text { Type of } \\
\text { Vent } \\
\text { System } \\
\text { (Active or } \\
\text { Passive) }\end{array}$} & \multirow{2}{*}{$\begin{array}{l}\text { Stabilization } \\
{ }^{(4)} \text { Status }\end{array}$} & \multirow{2}{*}{$\begin{array}{l}\text { Vent }^{(5)} \\
\text { Filter } \\
\text { Type }\end{array}$} & \multicolumn{7}{|c|}{ Requirements ${ }^{(6)}$} & \multirow[t]{2}{*}{ Comments } \\
\hline & & & & & $\operatorname{OSSR}^{(6 A)}$ & $\mathrm{S} / \mathrm{O}^{(6 \mathrm{~B})}$ & $\operatorname{ssc}^{(6 C)}$ & $\mathrm{TSR}^{(6 \mathrm{D})}$ & $\begin{array}{l}\text { IS(6E) } \\
\text { (for vent. } \\
\text { only) }\end{array}$ & $\begin{array}{l}\text { OSD } \\
13^{(6 F)}\end{array}$ & $\begin{array}{l}\text { OSD- } \\
30^{(E G)}\end{array}$ & \\
\hline $5 x-102$ & Hydrogen & A & $\mathrm{Pl}$ & $N / A$ & 3 & $2 Y$ & $Y$ & $\gamma$ & $\mathbf{N}$ & $Y$ & $\mathrm{Y}$ & $\begin{array}{l}\text { Risk assessment should be } \\
\text { performed } \\
\text { Need to comply whi is } \\
\text { Jentilation chiteria for } \\
\text { monitoring pressure and stack } \\
\text { adiation levels, }\end{array}$ \\
\hline $5 x-103$ & $\begin{array}{l}\text { Hydrogen/ } \\
\text { Organics }\end{array}$ & A & $\mathrm{PI}$ & NIA & 3 & $2, Y$ & $Y$ & $Y$ & N & $Y$ & $y$ & $\begin{array}{l}\text { Risk assessment should be } \\
\text { performed } \\
\text { Need to comply with is } \\
\text { Ventilation criteria for } \\
\text { monitoring pressure and stack } \\
\text { fadjation levels. }\end{array}$ \\
\hline $5 \times-104$ & Hydrogen & A & $P$ & $\mathrm{~N} / \mathrm{A}$ & 3 & $3, Y$ & $\mathbf{Y}$ & $y$ & $\mathbf{N}$ & $r$ & $Y$ & $\begin{array}{l}\text { Risk assessment should be } \\
\text { performed } \\
\text { Need to comply with is } \\
\text { yentilation chiteria for } \\
\text { nonitoring pressure and stack } \\
\text { adiation levels. }\end{array}$ \\
\hline $5 \times 105$ & Hydrogen & A & $\mathrm{PI}$ & NIA & 3 & $2 Y$ & $y$ & $y$ & N & $y$ & $Y$ & $\begin{array}{l}\text { Risk assessment should be } \\
\text { performed } \\
\text { Need to comply with is } \\
\text { Jentilation erteria for } \\
\text { monitorng pressure and stack } \\
\text { adiation levels. }\end{array}$ \\
\hline $5 \times 106$ & $\begin{array}{l}\text { Hydrogen/ } \\
\text { Organics }\end{array}$ & A & Pl & N/A & 3 & $2 Y$ & $\mathrm{Y}$ & $y$ & $\mathbf{N}$ & $y$ & $y$ & $\begin{array}{l}\text { Risk assessment should be } \\
\text { peftomed. } \\
\text { Need to comply with is } \\
\text { Jentlation criteria for } \\
\text { nonitoring pressure and stack } \\
\text { adiation levels. }\end{array}$ \\
\hline
\end{tabular}


HNF-SD-WM-ER-664, Rev. 0

\begin{tabular}{|c|c|c|c|c|c|c|c|c|c|c|c|c|}
\hline \multirow{2}{*}{$\begin{array}{l}\text { Tank ID } \\
\text { Number }\end{array}$} & \multirow{2}{*}{$\begin{array}{l}\text { Watch List }^{(2)} \\
\text { Status } \\
\text { (Justification) }\end{array}$} & \multirow{2}{*}{$\begin{array}{l}\text { Type of }{ }^{(3)} \\
\text { Vent } \\
\text { System } \\
\text { (Active or } \\
\text { Passive) }\end{array}$} & \multirow{2}{*}{$\begin{array}{l}\text { Stabilization } \\
{ }^{(4)} \text { Status }\end{array}$} & \multirow{2}{*}{$\begin{array}{l}\text { Vent }^{(5)} \\
\text { Fiter } \\
\text { Type }\end{array}$} & \multicolumn{7}{|c|}{ Requirements ${ }^{(6)}$} & \multirow[t]{2}{*}{ Comments } \\
\hline & & & & & $10 S R^{(6 A)}$ & $\mathrm{S} / \mathrm{O}^{(6 \mathrm{~B})}$ & $\operatorname{ssc}^{(60)}$ & $\operatorname{TSR}^{(6 \mathrm{D})}$ & $\begin{array}{l}\text { IS(6E) } \\
\text { (for vent. } \\
\text { only) }\end{array}$ & $\begin{array}{l}\text { OSD- } \\
13^{(6 F)}\end{array}$ & $\begin{array}{l}\text { OSD- } \\
30^{(6 G)}\end{array}$ & \\
\hline$s \times-107$ & Non-Watch list & A & IS/IP & N/A & 3 & $3, Y$ & $Y$ & $Y$ & $N$ & $Y$ & $Y$ & $\begin{array}{l}\text { Risk assessment should be } \\
\text { performed. } \\
\text { Need to comply with IS } \\
\text { yentilation criteria for monitoring } \\
\text { pressure and stack radiation } \\
\text { evels. } \\
\text { Heat load for this tank is > } \\
40,000 \mathrm{Btu} / \mathrm{hr} \text {. }\end{array}$ \\
\hline$S X-108$ & Non-Watch list & A & IS/IP & $N / A$ & 3 & $3, Y$ & Y & $Y$ & $\mathrm{~N}$ & $Y$ & $Y$ & $\begin{array}{l}\text { Risk assessment should be } \\
\text { performed. } \\
\text { Need to comply with is } \\
\text { yentilation criteria for } \\
\text { monitoring pressure and stack } \\
\text { adiation levels. } \\
\text { Heat load for this tank is > } \\
40,000 \mathrm{Btu} / \mathrm{hr} \text {. }\end{array}$ \\
\hline$\$ x-109$ & Hydrogen & A & ISAP & N/A & 3 & $2, Y$ & $Y$ & $y$ & $\mathrm{~N}$ & $Y$ & $Y$ & 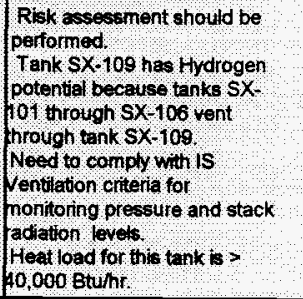 \\
\hline
\end{tabular}


HNF-SD-WM-ER-664, Rev. 0

\begin{tabular}{|c|c|c|c|c|c|c|c|c|c|c|c|c|}
\hline \multirow{2}{*}{$\begin{array}{l}\text { Tank ID } \\
\text { Number }\end{array}$} & \multirow{2}{*}{$\begin{array}{c}\text { Watch List }^{(2)} \\
\text { Status } \\
\text { (Justification) }\end{array}$} & \multirow{2}{*}{$\begin{array}{l}\text { Type of }{ }^{(3)} \\
\text { Vent } \\
\text { System } \\
\text { (Active or } \\
\text { Passive) }\end{array}$} & \multirow{2}{*}{$\begin{array}{l}\text { Stabilization } \\
{ }^{(4)} \text { Status }\end{array}$} & \multirow{2}{*}{$\begin{array}{l}\text { Vent }^{(5)} \\
\text { Fiter } \\
\text { Type }\end{array}$} & \multicolumn{7}{|c|}{ Requirements ${ }^{(6)}$} & \multirow[t]{2}{*}{ Comments } \\
\hline & & & & & $\operatorname{OSR}^{(6 A)}$ & $S / O^{(6 B)}$ & $\operatorname{SSC}^{(6 \mathrm{C})}$ & $\operatorname{TSR}^{(6 D)}$ & $\begin{array}{l}\text { IS(6e) } \\
\text { (for vent. } \\
\text { only) }\end{array}$ & $\begin{array}{l}\text { OSD- } \\
13^{(6 F)}\end{array}$ & $\begin{array}{l}\text { OSD- } \\
30^{(6 G)}\end{array}$ & \\
\hline$S X-110$ & Non-Watch list & A & IS/P & N/A & 3 & $3, Y$ & $Y$ & $Y$ & $\mathbf{N}$ & $Y$ & $Y$ & $\begin{array}{l}\text { Risk assessment should be } \\
\text { performed. } \\
\text { Need to comply with IS } \\
\text { yentilation criteria for } \\
\text { monitoring pressure and stack } \\
\text { adiation levels. } \\
\text { Heat load for this tank is > } \\
40,000 \mathrm{Btu} / \mathrm{hr} \text {. }\end{array}$ \\
\hline$s \times-111$ & Non-Watch list & A & ISIP & $N / A$ & 3 & $3, Y$ & $Y$ & Y & $N$ & $Y$ & $Y$ & $\begin{array}{l}\text { Risk assessment should be } \\
\text { performed. } \\
\text { Need to comply with is } \\
\text { yentilation criteria for } \\
\text { monitoring pressure and stack } \\
\text { fadiation leveis. } \\
\text { Heat load for this tank is > } \\
40,000 \mathrm{Btu} / \mathrm{hr} \text {. }\end{array}$ \\
\hline $5 X-112$ & Non-Watch list & A & ISAP & N/A & 3 & $3, Y$ & $Y$ & $Y$ & $N$ & $Y$ & $\curlyvee$ & $\begin{array}{l}\text { Risk assessment should be } \\
\text { performed. } \\
\text { Need to comply with is } \\
\text { ventilation criteria for } \\
\text { monitoring pressure and stack } \\
\text { adiation levels. } \\
\text { Heat load for this tank is > } \\
40,000 \mathrm{Btu} / \mathrm{hr} \text {. }\end{array}$ \\
\hline$S X-113$ & Non-Watch list & $\mathbf{P}$ & IS/P & $\begin{array}{l}\text { Open } \\
\text { Face }\end{array}$ & $Y$ & $3, Y$ & $Y$ & $Y$ & N/A & $Y$ & $Y$ & $\begin{array}{l}\text { Continue to maintain present } \\
\text { status. }\end{array}$ \\
\hline
\end{tabular}


HNF-SD-WM-ER-664, Rev. 0

\begin{tabular}{|c|c|c|c|c|c|c|c|c|c|c|c|c|}
\hline \multirow{2}{*}{$\begin{array}{l}\text { Tank ID } \\
\text { Number }\end{array}$} & \multirow{2}{*}{$\begin{array}{c}\text { Watch List }^{(2)} \\
\text { Status } \\
\text { (Justification) }\end{array}$} & \multirow{2}{*}{$\begin{array}{l}\text { Type of }{ }^{(3)} \\
\text { Vent } \\
\text { System } \\
\text { (Active or } \\
\text { Passive) }\end{array}$} & \multirow{2}{*}{$\begin{array}{l}\text { Stabilization } \\
{ }_{(4)}^{\text {Status }}\end{array}$} & \multirow{2}{*}{$\begin{array}{l}\text { Vent } \\
\text { Filter } \\
\text { Type }\end{array}$} & \multicolumn{7}{|c|}{ Requirements $^{(6)}$} & \multirow[t]{2}{*}{ Comments } \\
\hline & & & & & $\operatorname{los} R^{(6 A)}$ & $S / O^{(6 B)}$ & $\operatorname{ssc}^{(6 C)}$ & $\mathrm{TSR}^{(60)}$ & $\begin{array}{l}\text { IS }(6 \mathrm{E}) \\
\text { (for vent. } \\
\text { only) }\end{array}$ & $\begin{array}{l}\text { OSD } \\
13^{(6 F)}\end{array}$ & $\begin{array}{l}\text { OSD- } \\
30^{(6 G)}\end{array}$ & \\
\hline$s \times-114$ & Non-Watch list & A & ISAP & $N / A$ & 3 & $3, Y$ & $Y$ & N/A & $N$ & $Y$ & $Y$ & $\begin{array}{l}\text { Risk assessment should be } \\
\text { performed. } \\
\text { Need to comply with IS } \\
\text { rentilation criteria for monitoring } \\
\text { pressure and stack radiation } \\
\text { evels. } \\
\text { Heat load for this tank is > } \\
40,000 \text { Btu/hr. }\end{array}$ \\
\hline$S X-115$ & Non-Watch list & $P$ & IS/P & $\begin{array}{l}\text { Open } \\
\text { Face }\end{array}$ & $Y$ & $3, Y$ & $Y$ & $Y$ & $N / A$ & $Y$ & $Y$ & $\begin{array}{l}\text { Continue to maintain present } \\
\text { status. }\end{array}$ \\
\hline$T-101$ & Non-Watch list & $P$ & $|S / P|$ & $\begin{array}{l}\text { Open } \\
\text { Face }\end{array}$ & $Y$ & $3, Y$ & $Y$ & N/A & N/A & $Y$ & $Y$ & $\begin{array}{l}\text { Continue to maintain present } \\
\text { status. }\end{array}$ \\
\hline$T-102$ & Non-Watch list & $\mathrm{P}$ & IS/P & $\begin{array}{l}\text { Open } \\
\text { Face }\end{array}$ & $Y$ & $3, Y$ & $Y$ & N/A & N/A & $Y$ & $Y$ & $\begin{array}{l}\text { Continue to maintain present } \\
\text { status. }\end{array}$ \\
\hline$T-103$ & Non-Watch list & $P$ & $1 S / P$ & $\begin{array}{l}\text { Open } \\
\text { Face }\end{array}$ & $Y$ & $3, Y$ & $Y$ & N/A & N/A & $Y$ & $Y$ & $\begin{array}{l}\text { Continue to maintain present } \\
\text { status. }\end{array}$ \\
\hline$T-104$ & Non-Watch list & $P$ & $\mathrm{Pl}$ & $\begin{array}{l}\text { Open } \\
\text { Face }\end{array}$ & $Y$ & $3, Y$ & $Y$ & N/A & N/A & $Y$ & $Y$ & $\begin{array}{l}\text { Continue to maintain present } \\
\text { status. }\end{array}$ \\
\hline$T-105$ & Non-Watch list & $P$ & IS/IP & $\begin{array}{l}\text { Open } \\
\text { Face }\end{array}$ & $Y$ & $3, Y$ & $Y$ & N/A & N/A & $Y$ & $\mathrm{Y}$ & $\begin{array}{l}\text { Continue to maintain present } \\
\text { status. }\end{array}$ \\
\hline$T-106$ & Non-Watch list & $P$ & IS/IP & $\begin{array}{l}\text { Open } \\
\text { Face }\end{array}$ & $Y$ & $3, Y$ & $Y$ & N/A & N/A & $Y$ & $Y$ & $\begin{array}{l}\text { Continue to maintain present } \\
\text { status. }\end{array}$ \\
\hline$T-107$ & $\mathrm{FeCN}$ & $p$ & ISPI & Open & $Y$ & $3 Y$ & $Y$ & $N / A$ & N/A & $Y$ & $Y$ & $\begin{array}{l}\text { Cononue to maintatn present } \\
\text { tatus, }\end{array}$ \\
\hline$T-108$ & Non-Watch list & $P$ & IS/IP & $\begin{array}{l}\text { Open } \\
\text { Face }\end{array}$ & $Y$ & $3, Y$ & $Y$ & N/A & N/A & $Y$ & $Y$ & $\begin{array}{l}\text { Continue to maintain present } \\
\text { status. }\end{array}$ \\
\hline$T-109$ & Non-Watch list & $P$ & $\mid \mathrm{S} / \mathrm{P}$ & $\begin{array}{l}\text { Open } \\
\text { Face }\end{array}$ & $Y$ & $3, Y$ & $Y$ & N/A & N/A & $Y$ & $Y$ & $\begin{array}{l}\text { Continue to maintain present } \\
\text { status. }\end{array}$ \\
\hline
\end{tabular}


HNF-SD-WM-ER-664, Rev. 0

\begin{tabular}{|c|c|c|c|c|c|c|c|c|c|c|c|c|}
\hline \multirow{2}{*}{$\begin{array}{l}\text { Tank ID } \\
\text { Number }\end{array}$} & \multirow{2}{*}{$\begin{array}{l}\text { Watch List }{ }^{(2)} \\
\text { Status } \\
\text { (Justification) }\end{array}$} & \multirow{2}{*}{$\begin{array}{l}\text { Type of }{ }^{(3)} \\
\text { Vent } \\
\text { System } \\
\text { (Active or } \\
\text { Passive) }\end{array}$} & \multirow{2}{*}{$\begin{array}{l}\text { Stabilization } \\
\text { (4) Status }\end{array}$} & \multirow{2}{*}{\begin{tabular}{|l} 
Vent $^{(5)}$ \\
Filter \\
Type
\end{tabular}} & \multicolumn{7}{|c|}{ Requirements $^{(6)}$} & \multirow[t]{2}{*}{ Comments } \\
\hline & & & & & $\operatorname{OSSR}^{(6 \mathrm{~A})}$ & $S / O^{(68)}$ & $\operatorname{ssc}^{(6 \mathrm{C})}$ & $\operatorname{TSR}^{(6 \mathrm{D})}$ & $\begin{array}{l}\text { IS(6E) } \\
\text { (for vent. } \\
\text { only) }\end{array}$ & $\begin{array}{l}\text { OSD- } \\
13^{(6 F)}\end{array}$ & $\begin{array}{l}\text { OSD- } \\
30^{(6 G)}\end{array}$ & \\
\hline$T_{110}$ & Hydrogen & $P$ & $P$ & $\begin{array}{l}\text { Open } \\
\text { Face }\end{array}$ & $y$ & $2 Y$ & Y & NAA & N/A & $Y$ & $\checkmark$ & $\begin{array}{l}\text { Continue to maintain present } \\
\text { ftatus. }\end{array}$ \\
\hline $\mathrm{T}-111$ & Organics & $P$ & IS/PI & $\begin{array}{l}\text { Open } \\
\text { Face }\end{array}$ & $y$ & $3, Y$ & Y & N/A & N/A & $Y$ & Y & $\begin{array}{l}\text { Continue to maintain present } \\
\text { Btatus }\end{array}$ \\
\hline$T-112$ & Non-Watch list & $P$ & IS/P & $\begin{array}{l}\text { Open } \\
\text { Face }\end{array}$ & $Y$ & $3, Y$ & Y & N/A & N/A & Y & $Y$ & $\begin{array}{l}\text { Continue to maintain present } \\
\text { status. }\end{array}$ \\
\hline T-201 & Flam Gas USQ & $P$ & ISAP & $\begin{array}{l}\text { Open } \\
\text { Face }\end{array}$ & $Y$ & $2 Y$ & $y$ & N/A & N/A & $Y$ & $Y$ & $\begin{array}{l}\text { Continue to maintain present } \\
\text { tatus. }\end{array}$ \\
\hline$T-202$ & Flam Gas USQ & $P$ & ISAP & $\begin{array}{l}\text { Open } \\
\text { Face }\end{array}$ & $Y$ & $2 Y$ & Y & N/A & N/A & $Y$ & Y & $\begin{array}{l}\text { Continue to maintain present } \\
\text { tatus. }\end{array}$ \\
\hline $\mathrm{T}-203$ & Non-Watch list & $P$ & ISAP & $\begin{array}{l}\text { Open } \\
\text { Face }\end{array}$ & $Y$ & $3, Y$ & Y & N/A & N/A & r & $\gamma$ & $\begin{array}{l}\text { Continue to maintain present } \\
\text { status. }\end{array}$ \\
\hline $\mathrm{T} 204$ & Flam Gas USO & $P$ & ISAP & $\begin{array}{l}\text { Open } \\
\text { Face }\end{array}$ & Y & $2 Y$ & $Y$ & NIA & N/A & Y & Y & $\begin{array}{l}\text { Continue to maintain present } \\
\text { Ptatus. }\end{array}$ \\
\hline$T X-101$ & Non-Watch list & $P$ & IS/P & $\begin{array}{c}\text { G-1 } \\
\text { Housing }\end{array}$ & $Y$ & $3, Y$ & Y & N/A & N/A & $Y$ & r & $\begin{array}{l}\text { Continue to maintain present } \\
\text { status. }\end{array}$ \\
\hline TX-102 & Flam Gas USa & P & ISIP & Gousing & $\mathrm{r}$ & $2 Y$ & $y$ & N/A & N/A & Y & Y & $\begin{array}{l}\text { Continue to maintain present } \\
\text { ftatus }\end{array}$ \\
\hline TX-103 & Non-Watch list & $P$ & IS/IP & $\begin{array}{c}\text { G-1 } \\
\text { Housing }\end{array}$ & Y & $3, Y$ & Y & N/A & N/A & Y & $Y$ & $\begin{array}{l}\text { Continue to maintain present } \\
\text { status. }\end{array}$ \\
\hline$T X-104$ & Non-Watch list & $P$ & ISAP & $\begin{array}{c}\text { G-1 } \\
\text { Housing }\end{array}$ & $Y$ & $3, Y$ & Y & N/A & N/A & $Y$ & $\curlyvee$ & $\begin{array}{l}\text { Continue to maintain present } \\
\text { status. }\end{array}$ \\
\hline TX-105 & Organics & $\mathrm{P}$ & ISnP & Gousing & $Y$ & $3, Y$ & Y & N/A & NIA & Y & $Y$ & $\begin{array}{l}\text { Contrinte to maintain present } \\
\text { tatus. }\end{array}$ \\
\hline$T X-106$ & Non-Watch list & $P$ & ISAP & $\begin{array}{c}\text { G-1 } \\
\text { Housing }\end{array}$ & Y & $3, Y$ & Y & N/A & N/A & $\mathrm{Y}$ & $Y$ & $\begin{array}{l}\text { Continue to maintain present } \\
\text { status. }\end{array}$ \\
\hline
\end{tabular}


HNF-SD-WM-ER-664, Rev. 0

\begin{tabular}{|c|c|c|c|c|c|c|c|c|c|c|c|c|}
\hline \multirow{2}{*}{$\begin{array}{l}\text { Tank ID } \\
\text { Number }\end{array}$} & \multirow{2}{*}{$\begin{array}{l}\text { Watch List }{ }^{(2)} \\
\text { Status } \\
\text { (Justification) }\end{array}$} & \multirow{2}{*}{$\begin{array}{l}\text { Type of }{ }^{(3)} \\
\text { Vent } \\
\text { System } \\
\text { (Active or } \\
\text { Passive) }\end{array}$} & \multirow{2}{*}{$\begin{array}{l}\text { Stabilization } \\
{ }_{(4)}^{\text {Status }}\end{array}$} & \multirow{2}{*}{$\begin{array}{l}\text { Vent } \\
\text { Filter } \\
\text { Type }\end{array}$} & \multicolumn{7}{|c|}{ Requirements ${ }^{(6)}$} & \multirow[t]{2}{*}{ Comments } \\
\hline & & & & & $\operatorname{lOSR}^{(6 A)}$ & $\mathrm{S} / \mathrm{O}^{(6 \mathrm{~B})}$ & $\mathrm{SSC}^{(6 \mathrm{C})}$ & $\mathrm{TSR}^{(6 \mathrm{D})}$ & $\begin{array}{l}\text { IS } 6 E \text { ) } \\
\text { (for vent. } \\
\text { only) }\end{array}$ & $\begin{array}{l}\text { OSD- } \\
13^{(6 F)}\end{array}$ & $\begin{array}{l}\text { OSD- } \\
30^{(6 G)}\end{array}$ & \\
\hline $\mathrm{TX}-107$ & Non-Watch list & $P$ & IS/IP & $\begin{array}{c}\text { G-1 } \\
\text { Housing }\end{array}$ & $Y$ & $3, Y$ & $Y$ & $N / A$ & N/A & $Y$ & $Y$ & $\begin{array}{l}\text { Continue to maintain present } \\
\text { status. }\end{array}$ \\
\hline$T X-108$ & Non-Watch list & $\mathbf{P}$ & ISAP & $\begin{array}{c}\text { G-1 } \\
\text { Housing }\end{array}$ & $Y$ & $3, Y$ & $Y$ & $N / A$ & N/A & $Y$ & $Y$ & $\begin{array}{l}\text { Continue to maintain present } \\
\text { status. }\end{array}$ \\
\hline$T X-109$ & Non-Watch list & $P$ & ISAP & $\begin{array}{c}\text { G-1 } \\
\text { Housing }\end{array}$ & $Y$ & $3, Y$ & $Y$ & N/A & N/A & $Y$ & $Y$ & $\begin{array}{l}\text { Continue to maintain present } \\
\text { status. }\end{array}$ \\
\hline$T X-110$ & Non-Watch list & $P$ & IS/IP & $\begin{array}{c}\text { G-1 } \\
\text { Housing }\end{array}$ & $Y$ & $3, Y$ & $Y$ & N/A & N/A & $Y$ & $Y$ & $\begin{array}{l}\text { Continue to maintain present } \\
\text { tatus. }\end{array}$ \\
\hline $\mathrm{TX}-111$ & Flam Gas USQ & $P$ & ISAP & G-1 & $y$ & $2, Y$ & $Y$ & $N / A$ & $N / A$ & $Y$ & $Y$ & $\begin{array}{l}\text { Continue to maintan present } \\
\text { Status }\end{array}$ \\
\hline$T X-112$ & Flam Gas USQ & $P$ & ISAP & G-1 & $Y$ & $2 Y$ & $Y$ & $\mathrm{~N} / \mathrm{A}$ & N/A & $\mathbf{Y}$ & $\mathrm{r}$ & $\begin{array}{l}\text { Continue to maintain present } \\
\text { status. }\end{array}$ \\
\hline$T X-113$ & Non-Watch list & $\mathbf{P}$ & $I S / P$ & $\begin{array}{c}\text { G-1 } \\
\text { Housing }\end{array}$ & Y & $2, Y$ & $Y$ & N/A & N/A & $Y$ & $Y$ & $\begin{array}{l}\text { Continue to maintain present } \\
\text { status. }\end{array}$ \\
\hline$T X-114$ & Non-Watch list & $P$ & $|S /| P$ & $\begin{array}{l}\text { Open } \\
\text { Face }\end{array}$ & $Y$ & $3, Y$ & $Y$ & N/A & N/A & $Y$ & $Y$ & $\begin{array}{l}\text { Continue to maintain present } \\
\text { status. }\end{array}$ \\
\hline$T X-115$ & Non-Watch list & $P$ & IS/PP & $\begin{array}{l}\text { Open } \\
\text { Face }\end{array}$ & $Y$ & $2, Y$ & $Y$ & N/A & N/A & $Y$ & $Y$ & $\begin{array}{l}\text { Continue to maintain present } \\
\text { status. }\end{array}$ \\
\hline$T X-116$ & Non-Watch list & $\mathbf{P}$ & IS IIP & $\begin{array}{c}\text { G-1 } \\
\text { Housing }\end{array}$ & $Y$ & $3, Y$ & $Y$ & N/A & N/A & $Y$ & $Y$ & $\begin{array}{l}\text { Continue to maintain present } \\
\text { Etatus. }\end{array}$ \\
\hline$T X-117$ & Non-Watch list & $P$ & IS IP & $\begin{array}{c}\text { G-1 } \\
\text { Housing }\end{array}$ & Y & $3, Y$ & $Y$ & N/A & $N / A$ & $Y$ & $Y$ & $\begin{array}{l}\text { Continue to maintain present } \\
\text { status. }\end{array}$ \\
\hline TX-118 & Organics/ $\mathrm{eCN}$ & $P$ & IS/P & Gousing & $Y$ & $3, Y$ & $\mathrm{Y}$ & N/A & $N / A$ & Y & $y$ & $\begin{array}{l}\text { Contintre to maintan present } \\
\text { tatus. }\end{array}$ \\
\hline$T r-101$ & $\mathrm{FeCN}$ & $P$ & ISAPAS & Open & $Y$ & $3 Y$ & $y$ & NIA & $\mathrm{N} / \mathrm{A}$ & $Y$ & $y$ & $\begin{array}{l}\text { Conitinue to maintain present } \\
\text { ptatus. }\end{array}$ \\
\hline
\end{tabular}


HNF-SD-WM-ER-664, Rev. 0

\begin{tabular}{|c|c|c|c|c|c|c|c|c|c|c|c|c|}
\hline \multirow{2}{*}{$\begin{array}{l}\text { Tank ID } \\
\text { Number }\end{array}$} & \multirow{2}{*}{$\begin{array}{c}\text { Watch List } \\
\text { Status } \\
\text { (Justification) }\end{array}$} & \multirow{2}{*}{$\begin{array}{l}\text { Type of }{ }^{(3)} \\
\text { Vent } \\
\text { System } \\
\text { (Active or } \\
\text { Passive) }\end{array}$} & \multirow{2}{*}{$\begin{array}{l}\text { Stabilization } \\
{ }_{(4)}^{\text {Status }}\end{array}$} & \multirow{2}{*}{$\begin{array}{l}\text { Vent }^{(5)} \\
\text { Filter } \\
\text { Type }\end{array}$} & \multicolumn{7}{|c|}{ Requirements $^{(6)}$} & \multirow[t]{2}{*}{ Comments } \\
\hline & & & & & $\operatorname{IOS} R^{(6 A)}$ & $S / O^{(6 B)}$ & $\operatorname{SSC}^{(6 \mathrm{C})}$ & $\mathrm{TSR}^{(6 \mathrm{D})}$ & $\begin{array}{l}\text { IS(6E) } \\
\text { (for vent. } \\
\text { only) }\end{array}$ & $\begin{array}{l}\text { OSD- } \\
13^{(6 F)}\end{array}$ & $\begin{array}{l}\text { OSD- } \\
30^{(6 G)}\end{array}$ & \\
\hline TY-102 & Non-Watch list & P & IS/P/S & $\begin{array}{l}\text { Open } \\
\text { Face }\end{array}$ & $Y$ & $3, Y$ & $Y$ & N/A & $N / A$ & $Y$ & $Y$ & $\begin{array}{l}\text { Continue to maintain present } \\
\text { tatus. }\end{array}$ \\
\hline $\mathrm{TY}-103$ & $\mathrm{FeCN}$ & P & $1 S / \mathrm{P} / \mathrm{S}$ & Open & $\mathrm{Y}$ & $3 Y$ & $\mathbf{Y}$ & $N / A$ & N/A & $y$ & $\checkmark$ & Continue to maintain present \\
\hline$T Y-104$ & Organics/FeCN & $\rho$ & ISAPnS & Open & $Y$ & $3 y$ & $Y$ & NIA & $N / A$ & $Y$ & $\mathbf{Y}$ & Continue to maintain present \\
\hline$T Y-105$ & Non-Watch list & $P$ & IS/P/S & $\begin{array}{l}\text { Open } \\
\text { Face }\end{array}$ & $Y$ & $3, Y$ & $Y$ & N/A & N/A & $Y$ & $Y$ & $\begin{array}{l}\text { Continue to maintain present } \\
\text { status. }\end{array}$ \\
\hline TY-106 & Non-Watch list & $P$ & IS/IP/S & $\begin{array}{l}\text { Open } \\
\text { Face }\end{array}$ & $Y$ & $3, Y$ & $Y$ & N/A & N/A & $Y$ & $Y$ & $\begin{array}{l}\text { Continue to maintain present } \\
\text { status. }\end{array}$ \\
\hline U-101 & Non-Watch list & $P$ & $\mid S / I P$ & $\begin{array}{l}\text { Open } \\
\text { Face }\end{array}$ & $Y$ & $3, Y$ & $Y$ & N/A & N/A & $Y$ & $Y$ & $\begin{array}{l}\text { Continue to maintain present } \\
\text { tatus. }\end{array}$ \\
\hline U-102 & Non-Watch list & $P$ & PI & $\begin{array}{l}\text { Open } \\
\text { Face }\end{array}$ & $Y$ & $2, Y$ & $\mathrm{Y}$ & N/A & N/A & $Y$ & $Y$ & $\begin{array}{l}\text { Continue to maintain present } \\
\text { status. }\end{array}$ \\
\hline$\cup-103$ & $\begin{array}{l}\text { Hydrogent } \\
\text { Organics }\end{array}$ & $P$ & $\mathrm{Pl}$ & $\begin{array}{l}\text { Open } \\
\text { Face }\end{array}$ & $Y$ & $2 Y$ & $Y$ & N/A & $\mathrm{N} / \mathrm{A}$ & $y$ & $y$ & Conúnue to maintain present \\
\hline U-104 & Non-Watch list & $\mathrm{P}$ & IS/P & $\begin{array}{l}\text { Open } \\
\text { Face }\end{array}$ & $Y$ & $3, Y$ & $Y$ & N/A & N/A & $Y$ & $Y$ & $\begin{array}{l}\text { Continue to maintain present } \\
\text { status. }\end{array}$ \\
\hline U.105 & $\begin{array}{l}\text { Hydrogent } \\
\text { Organics. }\end{array}$ & P & PI & Open & $y$ & $2, Y$ & Y & N/A & N/A & $y$ & $y$ & Continsto to maintain present \\
\hline U-106 & Organics & $\mathbf{P}$ & $\mathrm{Pl}$ & $\begin{array}{l}\text { Open } \\
\text { Face }\end{array}$ & $\mathrm{Y}$ & $2, y$ & $Y$ & N/A & N/A & $Y$ & $Y$ & Continue to maintain present \\
\hline U-107 & $\begin{array}{l}\text { Hydrogent } \\
\text { Ofganics. }\end{array}$ & $p$ & PI & Open & $Y$ & $2 Y$ & $Y$ & N/A & N/A & $Y$ & $y$ & Continute to maintain present \\
\hline U-108 & Hydrogen & $P$ & PI & Open & $Y$ & $2, Y$ & $Y$ & $N / A$ & N/A & $y$ & $\checkmark$ & Continue to maintain present \\
\hline
\end{tabular}


HNF-SD-WM-ER-664, Rev. 0

\begin{tabular}{|c|c|c|c|c|c|c|c|c|c|c|c|c|}
\hline \multirow{2}{*}{$\begin{array}{l}\text { Tank ID } \\
\text { Number }\end{array}$} & \multirow{2}{*}{$\begin{array}{l}\text { Watch List }{ }^{(2)} \\
\text { Status } \\
\text { (Justification) }\end{array}$} & \multirow{2}{*}{$\begin{array}{l}\text { Type of } \\
\text { Vent } \\
\text { System } \\
\text { (Active or } \\
\text { Passive) }\end{array}$} & \multirow{2}{*}{$\begin{array}{l}\text { Stabilization } \\
{ }_{(4)}^{\text {Status }}\end{array}$} & \multirow{2}{*}{$\begin{array}{l}\text { Vent }^{(5)} \\
\text { Filter } \\
\text { Type }\end{array}$} & \multicolumn{7}{|c|}{ Requirements ${ }^{(6)}$} & \multirow[t]{2}{*}{ Comments } \\
\hline & & & & & $\operatorname{OOSR} R^{(6 A)}$ & $S / O^{(6 B)}$ & $\operatorname{ssc}{ }^{(6 C)}$ & $T S R^{(6 D)}$ & $\begin{array}{l}\text { IS(6E) } \\
\text { (for vent. } \\
\text { only) }\end{array}$ & $\begin{array}{l}\text { OSD- } \\
13^{(6 F)}\end{array}$ & $\begin{array}{l}\text { OSD- } \\
30^{(6 G)}\end{array}$ & \\
\hline $\mathrm{U}-109$ & Hydrogen & $P$ & pl & $\begin{array}{l}\text { Open } \\
\text { Face }\end{array}$ & $y$ & $2 Y$ & $y$ & NIA & NIA & $Y$ & $Y$ & Continue to maintain present \\
\hline U-110 & Non-Watch list & $P$ & $|S / P|$ & $\begin{array}{l}\text { Open } \\
\text { Face }\end{array}$ & $Y$ & $3, Y$ & $Y$ & N/A & N/A & $Y$ & $Y$ & $\begin{array}{l}\text { Continue to maintain present } \\
\text { status. }\end{array}$ \\
\hline U-711 & Organics & $P$ & Pl: & $\begin{array}{l}\text { Open } \\
\text { Face }\end{array}$ & $Y$ & $2 Y$ & $y$ & $\mathrm{~N} / \mathrm{A}$ & N/A & $Y$ & $Y$ & $\begin{array}{l}\text { Continue to maintain present } \\
\text { Status }\end{array}$ \\
\hline U-112 & Non-Watch list & $P$ & ISAP & $\begin{array}{l}\text { Open } \\
\text { Face }\end{array}$ & $Y$ & $3, Y$ & Y & N/A & N/A & $Y$ & $Y$ & $\begin{array}{l}\text { Continue to maintain present } \\
\text { ptatus. }\end{array}$ \\
\hline U-201 & Non-Watch list & $P$ & IS/P & $\begin{array}{l}\text { Open } \\
\text { Face }\end{array}$ & $Y$ & $3, Y$ & $Y$ & N/A & N/A & $Y$ & $Y$ & $\begin{array}{l}\text { Continue to maintain present } \\
\text { status. }\end{array}$ \\
\hline U.202 & Non-Watch list & $P$ & ISAP & $\begin{array}{l}\text { Open } \\
\text { Face }\end{array}$ & $Y$ & $3, Y$ & Y & N/A & N/A & $Y$ & $Y$ & $\begin{array}{l}\text { Continue to maintain present } \\
\text { status. }\end{array}$ \\
\hline U.203 & Organics: & $P$ & ISAP & Open & $\mathrm{Y}$ & $3 Y$ & $Y$ & N/A & N/A & $Y$ & $Y$ & $\begin{array}{l}\text { Continue to maintain present } \\
\text { tatus. }\end{array}$ \\
\hline $\mathrm{U}_{204}$ & Organics & $P$ & ISAP & Open & $Y$ & $3, Y$ & $Y$ & N/A & N/A & Y & $y$ & $\begin{array}{l}\text { Contunue to maintein present } \\
\text { ftatus }\end{array}$ \\
\hline
\end{tabular}




\section{FOOT NOTES}

1. Data presented in this table have been compiled from several source documents that are identified in the notes below.

- The shaded rows represent those SSTs that are on a Watch List.

2. The Watch List status for each tank is obtained from the document, Operating Specifications for Watch List Tanks (WHC 1996h).

- Several tanks, which were classified as non watch-list tanks before, are reclassified as "Flam Gas USQ." Watch list controls are required for these tanks pending further direction from DOE. Among 24 SSTs classified as Flam. Gas USQ, three tanks (BY-103, -105, and-106) are also on the FeCN watch list.

- A total of ten tanks are identified to generate heat in excess of 40,000 Btu/hr. SST C-106 is the only tank whose waste has a high enough heat load to continuously exceed the safety limit of $150^{\circ} \mathrm{C}\left(300^{\circ} \mathrm{F}\right)$ if not cooled (through addition of water [evaporative cooling] and through active ventilation [convective cooling]).

3. The type of ventilation system for each SST is identified in the report titled Waste Tank Summary Report for Month Ending May 30, 1996, (WHC 1996i). There are 15 SSTs that utilize active ventilation. The remaining 134 tanks are passively ventilated

4. The stabilization status of each tank is listed in Table E-6 in Waste Tank Summary Report for Month Ending May 30, 1996, WHC-EP-0182-99, August 1996. The controlled, clean, and stable (CCS) functions have been accomplished for six tanks, TY-101 through -106.

$$
\begin{array}{ll}
\text { IS } & \text { - Interim Stabilized } \\
\text { PI } & \text { - Partially Interim Isolated } \\
\text { IP } & \text { - Intrusion Prevention }
\end{array}
$$

Note: Refer to Appendix $C$ in the Waste Tank Summary Report of detail descriptions for these activities.

5. Breather filter types are taken from the report, An Engineering Review of Tank Farm Ventilation System (WHC 1994b).

6. Requirements for compliance were taken from several documents that were considered pertinent for evaluating the SST ventilation system. Based on the information available, a list of requirements was identified and is listed in Appendices B -- G. The letter " $Y$ " indicates that the requirement is met, letter " $N$ " indicates that the requirement is not met, and "N/A" indicates that this particular requirement is not applicable.

6.A. The reference document for this column is, Single-Shell Tanks Interim Operational Requirements (WHC 1994a). The non-compliant requirements are identified by numerical numbers. Refer to corresponding number(s) in Appendix B for the description of requirement(s).

6.B. The reference document for this column is West/East Tank Farms Standing Orders (FDH 1996a, $\mathrm{FDH}$ 1996b). The gas release events (GRE) were evaluated and underground the storage tanks were classified into three Facility Groups. All SSTs fit into Group 2 or 3 . The first number in this 
column indicates the group in which a particular tank is placed. Refer to corresponding number(s) in Appendix $\mathrm{C}$ for the description of requirement(s).

6.C. The reference document for this column is, TWRS Safety Structures, Systems, and Components: Requirements and Characteristics (WHC 1996d). Refer to corresponding number(s) in Appendix $D$ for the description of requirement(s).

6.D. The reference document for this column is, TWRS Technical Safety Requirements (WHC 1996c). All actively ventilated systems meet the requirement. All passively ventilated systems are marked N/A. Refer to Appendix $E$ for the description of requirements.

6.E. The reference document for this column is, Controlled, Clean, and Stable Functions and Endpoint Criteria for Single-Shell Tank Farms, (WHC 1996e). Refer to corresponding number(s) in Appendix $F$ for the description of requirement(s).

6.F. The reference document for this column is, Operating Specifications for Single-Shell Waste Storage Tanks (WHC 1996g). The non-compliant requirements are identified by numerical numbers. Refer to corresponding number(s) in Appendix $G$ for the description of requirement(s).

6.G. The reference document for this column is, Operating Specifications for Watch List Tanks (WHC1996h). Refer to corresponding number(s) in Appendix G for the description of requirement(s). 
HNF-SD-WM-ER-664, Rev. 0

\begin{abstract}
APPENDIX B
Functional Requirements from

Single-Shell Tank Interim Operational Safety Requirements
\end{abstract}

B-1 
This appendix lists the requirements from the Single-Shell Tank Operational Safety Requirements (WHC 1994a) which are applicable to SST ventilation systems. Additionally, a column has been provided to identify the implementing document that ensures the requirements are being met and/or the actual equipment configuration status of the tanks to ensure the requirements are being met.

Table B-1. OSR-005 Requirements Applicable to SST Ventilation Systems

\begin{tabular}{|c|c|c|c|}
\hline No. & Requirement & Reference & $\begin{array}{l}\text { Implementing Doc/ } \\
\text { Status or Configuration }\end{array}$ \\
\hline 1 & $\begin{array}{l}\text { Single-Shell Tank pressure monitoring system shall } \\
\text { be OPERABLE on actively ventilated tanks with a } \\
\text { maximum pressure of } 0 \text { inches water gauge. } \\
\text { The minimum pressure in each tank vapor space } \\
\text { relative to atmosphere shall be maintained. } \\
\text { a. For tanks with } z 10 \text { inches WASTE } \\
\text { maintain pressure } 2-9.5 \text { inches water } \\
\text { gauge. } \\
\text { b. For tanks with }<10 \text { but } \geq 4.5 \text { inches } \\
\text { WASTE maintain pressure } 2 \text { the } \\
\text { negative of (the WASTE height minus } \\
\text { O.5) in inches water gauge. } \\
\text { c. For tanks with }<4.5 \text { inches WASTE } \\
\text { maintain pressure } \geq 4 \text { inches water } \\
\text { gauge }\end{array}$ & $\begin{array}{l}\text { OSR-005 } \\
\text { LCO } 3.3 .1\end{array}$ & $\begin{array}{l}\text { TO-060-015 } \\
\text { TO-060-050 } \\
\text { TO-400-120 } \\
\text { TF-OR-EF-C-D } \\
\text { TF-OR-WST-02-D }\end{array}$ \\
\hline 2 & $\begin{array}{l}\text { Seal loops shall be OPERABLE on passively } \\
\text { ventilated tanks. }\end{array}$ & $\begin{array}{l}\text { OSR-005 } \\
\text { LCO } 3.3 .1\end{array}$ & $\begin{array}{l}\text { TO-060-015 } \\
\text { Daily Weekly round } \\
\text { sheets }\end{array}$ \\
\hline 3 & $\begin{array}{l}\text { Single-Shell Tank active ventilation exhaust stack } \\
\text { radiation monitoring system shall be OPERABLE }\end{array}$ & $\begin{array}{l}\text { OSR-005 } \\
\text { LCO } 3.4 .1\end{array}$ & $\begin{array}{l}\text { Active ventilation systems } \\
\text { are equipped with } \\
\text { continuous air monitors } \\
\text { (CAM) and record } \\
\text { samplers. }\end{array}$ \\
\hline
\end{tabular}


HNF-SD-WM-ER-664, Rev. 0

\section{APPENDIX C}

Functional Requirements from West/East Tank Farms Standing Orders 
The purpose of this $S / O$ is to specify the allowed safe conditions and control requirements that address the flammable gas hazards. Section 6 of this document identifies the required ventilation controls for SSTs. They are provided here for completeness.

The current ventilation controls as specified in the currently implemented Authorization Basis will be the compensatory actions until S/O Ventilation requirements are implemented.

In addition to the above the following controls will apply.

The specification limits of OSD-T-151-00013, section 13.2.2.D.2, for passive breathing pathways. (See Appendix $\mathrm{G}$ for details on compliance.)

Verify passive breather filter isolation valve is open, every 10 days, or establish an alternate ventilation path.

Additionally, Ignition Control (IC) Set requirements for manned and unmanned operations (also provided below) ensure that all of the safety limits are met. The IC Sets are provided below for completeness.

Single-shell tanks have been evaluated for the potential types of Gas Release Events (GRE) and categorized into Facility Groups 2 and 3 so that a matrix could be developed that implemented IC sets. A detailed identification of SST and its facility group is provided in Appendix A.

\section{C-1.0 Ignition Source Control Set 1}

This set is used for all equipment that is installed or used during work activities for that portion of the equipment that can contact the undiluted gases that are retained within the waste or are present in the vapor space of waste intruding equipment. The basis is that flammable conditions may be present often or always in these locations; and therefore, the highest level of control, consistent with NFPA 70 (NFPA 1993a) Class I, Division 1 is appropriate.

C-1.1 Mechanical tooling, equipment and materials (including lubricants, adhesives, gaskets, corrosion inhibitors, epoxies, etc.) shall be constructed of spark-resistant material, or shall be rendered incapable of sparking, or shall have been analyzed and evaluated to not be capable of sparking under the applied conditions (WHC 1990). Material compatibility shall be evaluated for thermite reaction potential (WHC 1996k).

C-1.2 Electrostatic ignition sources shall be controlled by providing bonding or grounding according to NFPA 77 (1993).

C-1.3 Exposed polymer materials shall be rendered incapable of electrostatic charge or discharge potential either by design or through acceptable workaround practices providing equivalent safety (NFPA 77 1993).

C-1.4 The surface temperatures of heat-generating devices shall not exceed $80 \%$ of the autoignition temperature of the flammable gas (for this Standing Order, this is defined as $80 \%$ of $520^{\circ} \mathrm{C}$ which equals $416^{\circ} \mathrm{C}\left[780^{\circ} \mathrm{F}\right]$ ). If the device can contact the waste and cause ignition by triggering exothermic reactions in the waste (i.e., organic-nitrate reactions) the surface temperature is limited to $160^{\circ} \mathrm{C}\left(320^{\circ} \mathrm{F}\right)$. Internal temperatures of heat generating devices may exceed these temperatures if isolated from the gas environment, or if the design of the device enclosure meets requirements for explosion-proof housings. 
C-1.5 Electrical equipment shall be designed to meet NFPA 70 (1996). Class I, Division 1, Group B criteria or equivalent safety. As a minimum, this shall be interpreted to mean that no single-point failure of energized equipment can result in an arc or spark, or gas burn propagation to the environment external to the source enclosure. In the case of waste-submerged equipment containing potential ignition sources, demonstration by design that the equipment is non-sparking under normal operation and is designed to be isolated from the waste environment is an acceptable alternative.

C-1.6 Shutdown of purged and pressurized electrical equipment and purged and pressurized heatgenerating equipment, upon loss of protective gas pressure or flow, shall be automatic by design as defined by NFPA 496 Type $X$ pressurization.

C-1.7 Interlocked start-up of purged and pressurized electrical or purged and pressurized heatgenerating equipment shall only be allowed upon system sensing of pre-set safety limits. If pressurized enclosures are used to isolate energized components, a minimum of four (4) enclosure volumes shall be purged through the enclosure for energized components, and/or ten (10) volumes shall be purged for enclosed motors prior to controlled start-up of the system components.

C-2.0 This set is applied to vapor space locations (ex-tank, intrusive and dome-intrusive) when a GRE is postulated to create flammable conditions. Set 2 is similar to Set 1 except that requirements (6) and (7) are modified to allow the use of more readily available equipment. The basis is that the flammable conditions are unlikely and would persist for relatively short periods of time.

\section{C-2.1 Ignition Source Control Set \# 1 items 1 through 4.}

C-2.2 Electrical equipment shall be designed to meet NFPA 70 (1996), Class 1, Division 2, Group B criteria or equivalent safety. As a minimum, this shall be interpreted to mean the equipment is non-sparking under normal operation or, if normally sparking, the sparking component(s) shall be continuously isolated (purged and pressurized) from the potentially flammable gas environment, or the design of the device enclosure shall be of sufficient strength (explosion-proof) to prevent propagation of a gas burn to the environment external to the enclosure.

C-2.3 Either automatic shutdown or alarming with manual shutdown will be required upon loss of protective gas pressure or flow as defined by NFPA 496 (1993) Type Z pressurization. In ex-tank area applications, electrical equipment that does not meet Class I, Division 2, Group B may be used, if it is automatically shutdown by combustible gas detection systems.

C-2.4 Automatic or manual start-up of purged and pressurized electrical or purged and pressurized heat-generating equipment shall only be allowed upon system sensing of pre-set safety limits . If pressurized enclosures are utilized to isolate energized components, a minimum of four (4) enclosure volumes shall be purged through the enclosure for energized components, or ten (10) volumes shall be purged for enclosed motors prior to controlled start-up of the system components. When combustible gas detection shut down systems are employed, start-up of equipment shall only be allowed once measured acceptable flammable gas levels are indicated.

The specific application of the Standing Order Ignition Source Controls and the determination of equivalencies can vary with different activities and facilities and equipment due to uniqueness in configurations, materials and specific spark source hazards present. Specific application of safety measures occurs at the operating procedure and work package level. The specific application is reviewed for compliance with the requirements and intent of the Standing Order controls. A Flammable Gas Equipment Advisory Board has been formed to determine when the specific 


\section{HNF-SD-WM-ER-664, Rev. 0}

application meets or provides equivalent safety, when appropriate. It is important to note that Ignition Source Control Sets 1 and 2 were developed to guide engineers to safe design of new equipment. For existing installed equipment and current processes, the flexibility for evaluating equivalent safety is necessary in order to continue using this equipment and those processes. This may require modifications in some cases, but not in others. 
HNF-SD-WM-ER-664, Rev. 0

\section{APPENDIX D}

Functional Requirements from

Tank Waste Remediation System

Safety Structures, Systems, and Components:

Requirements and Characteristics 
HNF-SD-WM-ER-664, Rev. 0

The Tank Waste Remediation System Basis for Interim Operation (WHC 1996b) (BIO) establishes an improved authorization basis for TWRS facilities and operations required for the storage management of high-level waste (current and future tank waste). The Tank Waste Remediation System Basis for Intenim Operation (WHC 1996b) provides the basis for the conclusion that authorized TWRS facility operations can be conducted safely until approval of the TWRS FSAR. Chapter 5 of The Tank Waste Remediation System Basis for Interim Operation (WHC 1996b), "Safety Analyses", documents the selection of controls for 23 accident scenarios, and supports the selection with confirming analyses. The selected controls will maintain the facility within a safe operating envelope and protect the facility worker, the onsite worker, the offsite public, and the environment. The safety analyses process of identifying safety systems, structures, and components (SSCs) involved a graded approach for applying design and quality requirements to engineered features that maintain or perform safety functions. Selection of controls was done by an experienced team which included operations, hazard analysis, accident analysis, management, engineering, and appropriate subject matter specialists. The Tank Waste Remediation System Safety Structures, Systems, and Components (WHC 1996d) supplements the Chapter 5 controls selection by providing a description of the attributes of the specific SSCs required to provide the necessary functions, and thereby supplies the information needed for derivation of the Technical Safety Requirements (TSRs) for the The Tank Waste Remediation System Basis for Interim Operation (WHC 1996b).

\section{SST Ventilation}

Safety Classification. The SST ventilation systems are identified as safety-class SSCs for the Flammable Gas Deflagrations accident.

Safety Function(s). Maintain flammable gas concentrations in tank dome spaces, due to steady state releases, below $25 \%$ of the LFL.

System Description. Active ventilation systems remove flammable gases from the following SSTs

- All tanks in Single-Shell Tank Farm 241-SX (except for 241-SX-113 and -115)

- SSTs 241-C-105 and -106

The remaining SSTs are equipped with passive ventilation systems. Active and passive systems are described below.

Active Ventilation. The systems draw outside air into the tanks through HEPA-filtered inlet stations. The air mixes with and displaces the flammable gases produced by the waste. The air/gas mixture is then removed from the tanks, filtered to remove radioactive particulates, and exhausted to the environment.

Active ventilation systems are vulnerable to drive train malfunctions, loss of electrical power, and control system trips due to malfunctioning process monitors. Mean time between failures (MTBF) has typically been very short by common industrial performance standards and has been measured in weeks. Equipment upgrades and improved maintenance procedures have proven that MTBF can be increased to a year or more.

Passive Ventilation. A passive ventilation consists of a filter housing, a HEPA filter, and a shutoff valve. The filter housing is fabricated with a riser adapter which allows the housing to be bolted directly to a 4-inch tank riser. The riser adapter contains a shutoff valve which is open during normal operation of the breather filter assembly. The shutoff valve is closed to isolate the HEPA filter from the tank so that aerosol testing of the filter can be completed. The valve is also used to isolate a filter that has failed the aerosol test, until the filter is replaced. The HEPA filter prevents the release of airborne radioactive particulates to the environment. 
Passive ventilation systems allow flammable gases to be exhausted from the SSTs whenever the tank vapor space pressure exceeds atmospheric pressure. Conversely, the system allows air into the tank when atmospheric pressure exceeds the vapor space pressure. This influx of additional air dilutes the concentration of flammable gas in the vapor space.

Passive ventilation systems are vulnerable to damage by out-of-control vehicles, rainwater intrusion (in some tanks) and breather filters plugged by airborne dust.

\section{Functional Requirements}

Active Ventilation. Single-shell tank active ventilation systems shall maintain a vacuum in the tank vapor space, relative to atmospheric pressure.

Passive Ventilation. A HEPA filtered flow path shall be provided to allow the vapor space pressure to be in equilibrium with the atmospheric pressure.

\section{System Evaluation}

Active Ventilation. Proper operation of the active ventilation systems shall be verified daily.

Passive Ventilation. The breather filter isolation valve must be checked weekly to ensure that flow path is unobstructed.

\section{Supporting SSCs}

Active Ventilation. Electrical power.

Passive Ventilation. None. 
HNF-SD-WM-ER-664, Rev. 0

\section{APPENDIXE}

Functional Requirements from

Tank Waste Remediation System

Technical Safety Requirements 
This appendix lists the requirements from the Tank Waste Remediation System Technical Safety Requirements (WHC 1996c) which are applicable to SST ventilation systems. Additionally, Table E-1 identifies the implementing document that ensures the requirements are being met and/or the actual equipment configuration status of the tanks to ensure the requirements are being met.

Table E-1. Technical Safety Requirements Applicable to SST Ventilation Systems

\begin{tabular}{|c|c|c|c|}
\hline No. & Requirement & Reference & $\begin{array}{l}\text { Implementing Doc/ } \\
\text { Status or Configuration }\end{array}$ \\
\hline 1 & $\begin{array}{l}\text { The Ventilation Stack CAM } \\
\text { Interlock system shall be } \\
\text { operable in SSTs with active } \\
\text { ventilation (C and SX tank } \\
\text { farms). }\end{array}$ & $\begin{array}{l}\text { TSR-006 } \\
\text { LCO } 3.1 .4\end{array}$ & $\begin{array}{l}\text { TO-060-050 } 105 / 106-C \text { Exhauster; } \\
\text { TO-400-120 } 241-S X \text { Exhauster; and } \\
\text { 6-TF-077 } \\
\begin{array}{l}\text { Stack Sampling and } \\
\text { Monitoring System } \\
\text { Maintenance. }\end{array} \\
\begin{array}{l}\text { Note: the above procedures may require some } \\
\text { changes to comply with TSR requirements. }\end{array}\end{array}$ \\
\hline 2 & $\begin{array}{l}\text { An active ventilation system } \\
\text { shall be operable in SSTs with } \\
\text { active ventilation systems. (C- } \\
105, C-106, S X-101, S X-102 \\
S X-103, S X-104, S X-105, S X- \\
106, S X-107, S X-108, S X-109 \\
S X-110, S X-111, S X-112 \text {, and } \\
S X-114) \text {. }\end{array}$ & $\begin{array}{l}\text { TSR-006 } \\
\text { LCO 3.2.2 }\end{array}$ & $\begin{array}{ll}\text { TO-060-050 } & \text { 105/106-C Exhauster; } \\
\text { TO-400-120 } & \text { SX Exhauster; } \\
\text { TF-OR-EF-C-D } & \text { C-Farm Daily Rounds; } \\
\text { TF-OR-EF-W ST-01-D SX Daily Rounds; } \\
\text { 6-TF-156 } & \text { HEPA Filter Aerosol Test ; } \\
\text { 6-TF-155 } & \text { Stack Air Flow Test; and } \\
\text { 6-TF-237 } & \text { Fan Inspection. } \\
& \\
\text { Note: The above procedures may require some } \\
\text { changes to comply with TSR requirements. }\end{array}$ \\
\hline 3 & $\begin{array}{l}\text { The HEPA breather filter } \\
\text { isolation valve shall be open and } \\
\text { no blank installed in passively } \\
\text { ventilated SSTs. }\end{array}$ & $\begin{array}{l}\text { TSR-006 } \\
\text { LCO } 3.2 .3\end{array}$ & 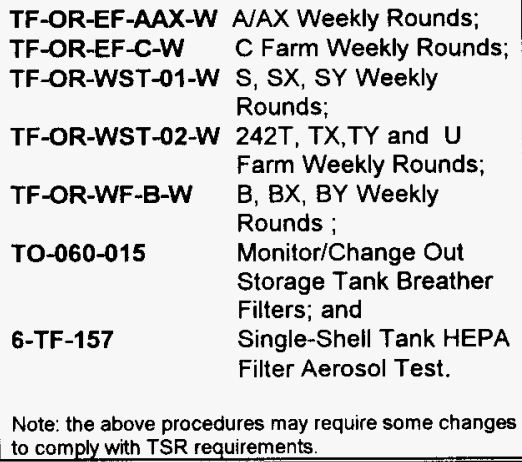 \\
\hline
\end{tabular}


HNF-SD-WM-ER-664, Rev. 0

\title{
APPENDIX F
}

\author{
Interim Stabilization \\ Functional Requirements
}


This appendix provides a table identifying the actively ventilated SSTs and their status/ configuration for meeting the IS ventilation requirements as called out in the, Controlled, Clean, and Stable Design Requirements Document for Single-Shell Tanks (WHC 1996e), Sections 3.2.1.1.5; 3.2.1.1.5.1 - 3.2.1.1.5.2). Interim Stabilization requires each actively ventilated tank to be monitored remotely (e.g., connected to TMACS). The instrumentation components associated with the ventilation systems required to be connected to TMACS are 1) pressure monitoring and 2) exhaust stack radiation monitoring (CAM). Requirements for passively ventilated IS tanks are met through standard tank farms "rounds sheets" (verification checks at defined intervals of time.)

Table F-1. Actively Ventilated Tanks Interim Stabilization Compliance

\begin{tabular}{|c|c|c|c|c|}
\hline No. & $\begin{array}{l}\text { Tank } \\
\text { No. }\end{array}$ & $\begin{array}{l}\text { Pressure } \\
\text { Monitoring }\end{array}$ & $\begin{array}{c}\text { Exhaust } \\
\text { Stack } \\
\text { Radiation } \\
\text { Monitoring } \\
\end{array}$ & $\begin{array}{c}\text { Meets } \\
\text { IS } \\
\text { Criteria }\end{array}$ \\
\hline 1 & $C-105$ & No & No & No \\
\hline 2 & C-106 & Yes & No & No \\
\hline 3 & $S x-101$ & No & No & No \\
\hline 4 & $5 X-102$ & No & No & No \\
\hline 5 & $s x-103$ & No & No & No \\
\hline 6 & $5 X-104$ & No & No & No \\
\hline 7 & $S X-105$ & No & No & No \\
\hline 8 & $S X-106$ & No & No & No \\
\hline 9 & SX-107 & No & No & No \\
\hline 10 & $S X-108$ & No & No & No \\
\hline 11 & $s \times-109$ & No & No & No \\
\hline 12 & $s x-110$ & No & No & No \\
\hline 13 & $S X-111$ & No & No & No \\
\hline 14 & $S X-112$ & No & No & No \\
\hline 15 & $5 x-114$ & No & No & No \\
\hline
\end{tabular}

Reference: Waste Tank Summary Report for Month Ending May 31, 1996 (WHC 1996i) 


\section{APPENDIX G}

Functional Guidelines from the

Tank Waste Remediation System

Operational Specifications Documents 
This appendix lists functional requirements from the Operating Specifications Document for Single-Shell Waste Storage Tanks (OSD-T-151-00013) and the Operating Specifications for Watch List Tanks (OSD-T-151-00030) which are applicable to SST ventilation systems. Additionally, a column has been provided to identify the implementing document that ensures the requirements are being met and/or the actual equipment configuration status of the tanks to ensure the requirements are being met.

Table G-1. OSD-13-T-0013 and OSD-30-T-151-0030 Functional Requirements Applicable to SST Ventilation Systems

\begin{tabular}{|c|c|c|c|}
\hline No. & Requirement & Reference & $\begin{array}{l}\text { Implementing Docl } \\
\text { Status or Configuration }\end{array}$ \\
\hline 1 & $\begin{array}{l}\text { Vapor space pressure in SSTs shall be minimum of } \\
1 \text { in. wg.- Waste height (in. wg) not to exceed - } 9 \\
\text { in. wg. }\end{array}$ & $\begin{array}{l}\text { OSD-13 } \\
13.2 .1 . F\end{array}$ & $\begin{array}{l}\text { TO-060-015 } \\
\text { TO-060-050 } \\
\text { TO-400-120 }\end{array}$ \\
\hline 2 & $\begin{array}{l}\text { A pressure gauge shall be installed at the tank side } \\
\text { inlet of each exhauster (an acceptable alternative } \\
\text { location is on a tank riser). Pressure is to be } \\
\text { recorded at least every } 24 \text { hours on actively } \\
\text { ventilated tanks. }\end{array}$ & $\begin{array}{l}\text { OSD-13 } \\
13.2 .1 . F\end{array}$ & $\begin{array}{l}\text { TF-OR-EF-C-D } \\
\text { TF-OR-WST-02-D } \\
\text { WHC-EP-0479-1 Facility } \\
\text { Effluent Monitoring Plan } \\
\text { for Tank Farm Facility } \\
\text { Tables 7-18 and 7-26. }\end{array}$ \\
\hline 3 & $\begin{array}{l}\text { A seal loop, which evacuates at } 4 \pm 1 \text { in. wg, shall } \\
\text { be installed on each passively ventilated tank. The } \\
\text { seal fluid shall be nonvolatile, with a specific gravity } \\
\text { as close to } 1.0 \text { as practical. The liquid level shall } \\
\text { be maintained at } 4 \pm 1 \text { inches, and the seal loop } \\
\text { status recorded. } \\
\text { Loop fluid levels on passively ventilated tanks shall } \\
\text { be checked at least every } 10 \text { days and refilled if } \\
\text { necessary. }\end{array}$ & $\begin{array}{l}\text { OSD-13 } \\
13.2 .1 . F\end{array}$ & $\begin{array}{l}\text { TO-060-015 Daily/weekly } \\
\text { Round sheets }\end{array}$ \\
\hline 4 & $\begin{array}{l}\text { Active ventilation shall be installed for cooling any } \\
\text { SST which: 1) is expected to reach a peak high } \\
\text { temperature which exceeds the maximum } \\
\text { operating specification (see 13.2.1.E or } 2 \text { ) contains } \\
\text { waste projected to boil. }\end{array}$ & $\begin{array}{l}\text { OSD-13 } \\
13.2 .1 . G\end{array}$ & $\begin{array}{l}\text { Active ventilation was } \\
\text { installed on } 16 \text { SSTs } \\
\text { which showed } \\
\text { temperature higher than } \\
147^{\circ} \mathrm{C}\left(300^{\circ} \mathrm{F}\right) \text {. Tank } \\
\text { Farm ' A' exhauster was } \\
\text { shutdown in October } 1991 \\
\text { and SX-farm ventilation } \\
\text { system has exceeded its } \\
\text { design life. }\end{array}$ \\
\hline
\end{tabular}


HNF-SD-WM-ER-664, Rev. 0

\begin{tabular}{|c|c|c|c|}
\hline No. & Requirement & Reference & $\begin{array}{l}\text { Implementing Doc } \\
\text { Status or Configuration }\end{array}$ \\
\hline 5 & $\begin{array}{l}\text { The annual average concentration of radionuclides } \\
\text { released from a SST to the environment, in } \\
\text { airborne effluents shall not exceed the derived } \\
\text { concentration guides specified in Appendix C, } \\
\text { WHC-CM-7-5. }\end{array}$ & $\begin{array}{l}\text { OSD-13 } \\
13.2 .2 . \mathrm{B}\end{array}$ & $\begin{array}{l}\text { Active ventilation systems } \\
\text { are equipped with CAMs } \\
\text { and record samplers. } \\
\text { Continuous air monitors } \\
\text { are interlocked to } \\
\text { shutdown the ventilation } \\
\text { fan when radionuclides } \\
\text { exceed the high level set } \\
\text { point. WHC-EP-0479-1 } \\
\text { Facility Effluent Monitoring } \\
\text { Plan for Tank Farm } \\
\text { Facility Table 7-2 lists the } \\
\text { CAM Alarm set points. } \\
\text { WHC-EP-0479-1 Facility } \\
\text { Effluent Monitoring Plan } \\
\text { for Tank Farm Facility } \\
\text { Table } 7-1 \text { lists the } \\
\text { emission limits (Alpha and } \\
\text { Beta) for various } \\
\text { exhausters. }\end{array}$ \\
\hline 6 & $\begin{array}{l}\text { The two week average concentration of } \\
\text { radionuclides released from a SST to the } \\
\text { environment, in airborne effluents, shall not exceed } \\
\text { four times the derived concentration guides } \\
\text { specified in Appendix C, WHC-CM-7-5. }\end{array}$ & $\begin{array}{l}\text { OSD-13 } \\
13.2 .2 .8\end{array}$ & $\begin{array}{l}\text { Active ventilation systems } \\
\text { are equipped with CAMs } \\
\text { and record samplers. } \\
\text { Continuous air monitors } \\
\text { are interlocked to } \\
\text { shutdown the ventilation } \\
\text { fan when radionuclides } \\
\text { exceed the high level set } \\
\text { point. } \\
\text { WHC-EP-0479-1 Facility } \\
\text { Effluent Monitoring Plan } \\
\text { for Tank Farm Facility) } \\
\text { Table 7-2 lists the CAM } \\
\text { Alarm set points. } \\
\text { WHC-EP-0479-1 Facility } \\
\text { Effluent Monitoring Plan } \\
\text { for Tank Farm Facility } \\
\text { Table } 7-1 \text { lists the } \\
\text { emission limits (Alpha and } \\
\text { Beta) for various } \\
\text { exhausters. }\end{array}$ \\
\hline
\end{tabular}


HNF-SD-WM-ER-664, Rev. 0

\begin{tabular}{|c|c|c|c|}
\hline No. & Requirement & Reference & $\begin{array}{l}\text { Implementing Docl } \\
\text { Status or Configuration }\end{array}$ \\
\hline 7 & $\begin{array}{l}\text { The maximum instantaneous concentration } \\
\text { of radionuclides released to the environment in } \\
\text { airborne effluents shall not exceed } 5000 \text { times the } \\
\text { derived concentration guides specified in Appendix } \\
\text { C, WHC-CM-7-5. }\end{array}$ & $\begin{array}{l}\text { OSD-13 } \\
13.2 .2 . \mathrm{B}\end{array}$ & $\begin{array}{l}\text { Active ventilation systems } \\
\text { are equipped with CAMs } \\
\text { and record samplers. } \\
\text { Continuous air monitors } \\
\text { are interlocked to } \\
\text { shutdown the ventilation } \\
\text { fan when radionuclides } \\
\text { exceed the high level set } \\
\text { point. } \\
\text { WHC-EP-0479-1 Facility } \\
\text { Effluent Monitoring Plan } \\
\text { for Tank Farm Facility } \\
\text { Table 7-2 lists the CAM } \\
\text { Alarm set points. } \\
\text { WHC-EP-0479-1 Facility } \\
\text { Effluent Monitoring Plan } \\
\text { for Tank Farm Facility } \\
\text { Table 7-1 lists the } \\
\text { emission limits (Alpha and } \\
\text { Beta) for various } \\
\text { exhausters. }\end{array}$ \\
\hline 8 & $\begin{array}{l}\text { All tank risers and pits except the exhauster } \\
\text { connection shall be sealed prior to any planned } \\
\text { shutdown }\end{array}$ & $\begin{array}{l}\text { OSD-13 } \\
13.2 .2 . \mathrm{C}\end{array}$ & $\begin{array}{l}\text { Work instructions in the } \\
\text { work package will address } \\
\text { these requirements. }\end{array}$ \\
\hline 9 & $\begin{array}{l}\text { All tanks on active ventilators shall have two stages } \\
\text { of High Efficiency Particulate Air (HEPA) filtration in } \\
\text { the outlet stream. } \\
\text { Air inlets for active ventilation systems shall be } \\
\text { HEPA filtered. }\end{array}$ & $\begin{array}{l}\text { OSD-13 } \\
13.2 .2 . D\end{array}$ & SAR-006 Section 5.2.6.1 \\
\hline 10 & $\begin{array}{l}\text { All SSTs shall be passively ventilated using HEPA } \\
\text { breather filters even if active ventilation is } \\
\text { temporarily installed. }\end{array}$ & $\begin{array}{l}\text { OSD-13 } \\
13.2 .2 . D\end{array}$ & SAR-006, Section 5.2.6.2 \\
\hline 11 & $\begin{array}{l}\text { Filter Differential Pressure in first filter in a series } \\
\text { shall have maximum } 5.9 \text { in. } w g \text { and } \\
\text { minimum } 0.05 \text { in. } w g\end{array}$ & $\begin{array}{l}\text { OSD-13 } \\
13.2 .2 . \mathrm{E}\end{array}$ & $\begin{array}{l}\text { TO-060-015 } \\
\text { Daily/Weekly Round } \\
\text { Sheets }\end{array}$ \\
\hline 12 & $\begin{array}{l}\text { Filter Differential Pressure in other filter in a series } \\
\text { shall have maximum } 4.0 \text { in. wg and } \\
\text { minimum } 0.05 \text { in. wg }\end{array}$ & $\begin{array}{l}\text { OSD-13 } \\
\text { 13.2.2.E }\end{array}$ & $\begin{array}{l}\text { TO-060-015 } \\
\text { Daily/Weekly Round } \\
\text { Sheets }\end{array}$ \\
\hline 13 & $\begin{array}{l}\text { Filter Differential Pressure in total series of filters } \\
\text { shall have maximum } 5.9 \mathrm{in.} w \mathrm{wg} \text { and } \\
\text { minimum } 0.05 \mathrm{in} . \mathrm{wg}\end{array}$ & $\begin{array}{l}\text { OSD-13 } \\
13.2 .2 . E\end{array}$ & $\begin{array}{l}\text { TO-060-015 } \\
\text { Daily/Weekly Round } \\
\text { Sheets }\end{array}$ \\
\hline
\end{tabular}


HNF-SD-WM-ER-664, Rev. 0

\begin{tabular}{|c|c|c|c|}
\hline No. & Requirement & Reference & $\begin{array}{l}\text { Implementing Dod } \\
\text { Status or Configuration }\end{array}$ \\
\hline 14 & HEPA Filter Temperature shall be $\leq 200^{\circ} \mathrm{F}$ & $\begin{array}{l}\text { OSD-13 } \\
13.2 .2 . F\end{array}$ & $\begin{array}{l}\text { TO-060-050 } \\
\text { TO-400-120 }\end{array}$ \\
\hline 15 & $\begin{array}{l}\text { HEPA Filter shall have minimum Efficiency of } \\
99.95 \% \text { for } 0.3 \text { um particles. }\end{array}$ & $\begin{array}{l}\text { OSD-13 } \\
13.2 .2 . G\end{array}$ & $\begin{array}{l}\text { 6-TF-156 } \\
\text { 6-TF-157 }\end{array}$ \\
\hline 16 & $\begin{array}{l}\text { Single-shell tanks having Heat Generation Rate } \\
\text { greater than } 40,000 \text { BTU/hr shall be designated as } \\
\text { High Heat Tanks requiring temperature monitoring } \\
\text { and/or active cooling to maintain acceptable } \\
\text { temperatures. }\end{array}$ & $\begin{array}{l}\text { OSD-13 } \\
13.2 .6 . B\end{array}$ & $\begin{array}{l}\text { Table A-3 of Waste Tank } \\
\text { summary report for month } \\
\text { ending May } 31,1996 .\end{array}$ \\
\hline 17 & $\begin{array}{l}\text { Sample tank breather filter outlet before breaking } \\
\text { containment per Flammable Control Limits }\end{array}$ & $\begin{array}{l}\text { OSD-13 } \\
13.4 .1 .1 . B \\
13.4 .1 .2 . B\end{array}$ & $\begin{array}{l}\text { Job Hazard Analysis } \\
\text { before any work starts, } \\
\text { will determine the need } \\
\text { for sampling. Vapor } \\
\text { spaces will be sampled } \\
\text { per WHC-SD-WM-HSP- } \\
002 \text {. }\end{array}$ \\
\hline 18 & $\begin{array}{l}\text { For Tank Intrusive or Non-Tank Intrusive work in } \\
\text { Tanks with passive ventilation systems or active } \\
\text { ventilation system not in operation } \\
\text { Spark resistant tools required for all openings }>1 \\
\text { inch inner diameter until monitoring shows }<25 \% \text { of } \\
\text { the LFL inside the work space. }\end{array}$ & $\begin{array}{l}\text { OSD-13 } \\
\text { 13.4.1.1.B } \\
13.4 .1 .2 . B\end{array}$ & $\begin{array}{l}\text { The J-4A instructions in } \\
\text { the work package will } \\
\text { address these restrictions. } \\
\text { The \% LFL will be } \\
\text { obtained using portable } \\
\text { Combustible Gas Monitor. }\end{array}$ \\
\hline 19 & $\begin{array}{l}\text { For Tank Intrusive or Non-Tank intrusive work in } \\
\text { Tanks with passive ventilation systems or active } \\
\text { ventilation system not in operation: } \\
\text { Electrical bonding per NFPA } 77 \text { of flange, cap, etc. } \\
\text { to be removed is required for all openings }>1 \text { inch } \\
\text { inner diameter until monitoring shows }<25 \% \text { of the } \\
\text { LFL inside the work space. }\end{array}$ & $\begin{array}{l}\text { OSD-13 } \\
\text { 13.4.1.1.B } \\
13.4 \cdot 1.2 . \mathrm{B}\end{array}$ & $\begin{array}{l}\text { The J-4A instructions in } \\
\text { the work package will } \\
\text { address these restrictions. } \\
\text { The \% LFL will be } \\
\text { obtained using portable } \\
\text { Combustible Gas Monitor. }\end{array}$ \\
\hline 20 & $\begin{array}{l}\text { A vapor sample shall be taken at a nominal three } \\
\text { feet inside the opening prior to start of work or as } \\
\text { close to that depth as practical. }\end{array}$ & $\begin{array}{l}\text { OSD-13 } \\
\text { 13.4.1.1.B }\end{array}$ & $\begin{array}{l}\text { The J-4A instructions in } \\
\text { the work package will } \\
\text { address these restrictions. }\end{array}$ \\
\hline 21 & $\begin{array}{l}\text { For Non-Tank Intrusive work in Tanks with active } \\
\text { ventilation system; } \\
\text { Spark resistant tools required for all openings }>1 \\
\text { inch inner diameter until vapor sampling } \\
\text { demonstrates the flammable gas concentration is } \\
<25 \% \text { of the LFL inside the work space. }\end{array}$ & $\begin{array}{l}\text { OSD-13 } \\
13.4 .2 .1 . B\end{array}$ & $\begin{array}{l}\text { The J-4A instructions in } \\
\text { the work package will } \\
\text { address these restrictions. } \\
\text { The \% LFL will be } \\
\text { obtained using portable } \\
\text { Combustible Gas Monitor. }\end{array}$ \\
\hline
\end{tabular}


HNF-SD-WM-ER-664, Rev. 0

\begin{tabular}{|c|c|c|c|}
\hline No. & Requirement & Reference & $\begin{array}{l}\text { Implementing Docd } \\
\text { Status or Configuration }\end{array}$ \\
\hline 22 & $\begin{array}{l}\text { For Non-Tank Intrusive work in Tanks with active } \\
\text { ventilation system; } \\
\text { Electrical bonding per NFPA } 77 \text { of flange, cap, etc. } \\
\text { to be removed is required for all openings }>1 \text { inch } \\
\text { inner diameter until vapor sampling demonstrates } \\
\text { the flammable gas concentration is }<25 \% \text { of the } \\
\text { LFL inside the work space. }\end{array}$ & $\begin{array}{l}\text { OSD-13 } \\
13.4 .2 .1 . \mathrm{B}\end{array}$ & $\begin{array}{l}\text { The J-4A instructions in } \\
\text { the work package will } \\
\text { address these restrictions. } \\
\text { The \% LFL will be } \\
\text { obtained using portable } \\
\text { Combustible Gas Monitor. }\end{array}$ \\
\hline 23 & $\begin{array}{l}\text { For Tank Intrusive work in Tanks with active } \\
\text { ventilation system; } \\
\text { Spark resistant tools required until vapor sampling } \\
\text { demonstrates the flammable gas concentration is } \\
<25 \% \text { of the LFL inside the work space. }\end{array}$ & $\begin{array}{l}\text { OSD-13 } \\
13.4 \cdot 2.2 . B\end{array}$ & $\begin{array}{l}\text { The J-4A instructions in } \\
\text { the work package will } \\
\text { address these restrictions. } \\
\text { The \% LFL will be } \\
\text { obtained using portable } \\
\text { Combustible Gas Monitor. }\end{array}$ \\
\hline 24 & $\begin{array}{l}\text { For Tank Intrusive work in Tanks with active } \\
\text { ventilation system; } \\
\text { Electrical bonding per NFPA } 77 \text { (NFPA 1993b) of } \\
\text { flange, cap, etc. to be removed is required until } \\
\text { vapor sampling demonstrates the flammable gas } \\
\text { concentration is < } 25 \% \text { of the LFL inside the work } \\
\text { space. }\end{array}$ & $\begin{array}{l}\text { OSD-13 } \\
13.4 .2 .2 . B\end{array}$ & $\begin{array}{l}\text { The J-4A instructions in } \\
\text { the work package will } \\
\text { address these restrictions. } \\
\text { The \% LFL will be } \\
\text { obtained using portable } \\
\text { Combustible Gas Monitor. }\end{array}$ \\
\hline 25 & $\begin{array}{l}\text { When working in primary ventilation space } \\
\text { (including dome space) or associated exhaust } \\
\text { ventilation system of a Hydrogen/Flammable Gas } \\
\text { and organic tank, use spark resistant tools and } \\
\text { flammable gas concentrations shall be }<25 \% \text { of the } \\
\text { LFL. }\end{array}$ & $\begin{array}{l}\text { OSD-30 } \\
\text { 30.2.A.1.A, } \\
\text { 30.2.C.1.B }\end{array}$ & $\begin{array}{l}\text { The J-4A instructions in } \\
\text { the work package will } \\
\text { address these restrictions. } \\
\text { The \% LFL will be } \\
\text { obtained/ monitored using } \\
\text { portable Combustible Gas } \\
\text { Monitor or SHMS. }\end{array}$ \\
\hline
\end{tabular}


HNF-SD-WM-ER-664, Rev. 0

\section{APPENDIX H}

\section{PRELIMINARY COST ESTIMATES}


Although this needs analysis report does not recommend any major ventilation system upgrades to maintain safe operation, it has identified possibilities for upgrades.

Preliminary Rough Order of Magnitude (ROM) cost estimates based on knowledge and experience of recommended system upgrades are required to complete the deliverable.

Several SSTs in the 241-SX-farm are on the watch list for Hydrogen/Flammable Gas, Organic and High Heat categories. Many studies have been conducted for evaluation of the ventilation system of 241-SX-farm. All the studies have concluded that the present ventilation system has exceeded its design life. All these studies have recommended that present ventilation system is not adequate and should be upgraded. The existing system should at least undergo a risk assessment to identify a basis for upgrading the system or for recommending the system be removed from active ventilation requirements and upgraded as necessary as a passive ventilation system.

The following tables list the ROM estimates for recommended upgrades for 241-SX-farm Ventilation System and need to be verified/updated when this project gets validated and complete scope of work is defined. Table $\mathrm{H}-1$ estimates the cost of actual equipment, and table $\mathrm{H}-2$ incorporates the cost of actual equipment with additional ROM estimates for complete system redesign, construction, and implementation of a new system. It is practical for the near future to first determine the need for an active ventilation system, and then proceed with component upgrades as necessary.

Table H-1. Estimated Equipment Cost for 241-SX Tank Farm Ventilation System Upgrades

\begin{tabular}{|l|c|}
\hline \multicolumn{1}{|c|}{ Equipment Needed * } & Estimated Cost (Dollars) \\
\hline Moisture Eliminator & $10 \mathrm{~K}$ \\
\hline Pre-filter & $10 \mathrm{~K}$ \\
\hline HEPA Filter (2 stage) & $30 \mathrm{~K}$ \\
\hline Fan & $20 \mathrm{~K}$ \\
\hline Stack Monitoring & $20 \mathrm{~K}$ \\
\hline Stack Ductwork & $10 \mathrm{~K}$ \\
\hline Instrument \& Controls & $10 \mathrm{~K}$ \\
\hline Miscellaneous Equipment & $40 \mathrm{~K}$ \\
\hline Total & $150 \mathrm{~K}$ \\
\hline
\end{tabular}

* Reference: Initial Assessment Report HVAC Systems (WHC 1996k). 
HNF-SD-WM-ER-664, Rev. 0

Table H-2. Estimated Cost of 241-SX Tank Farm Ventilation Redesign, Construction, and Implementation.

\begin{tabular}{||l|c|}
\hline \multicolumn{1}{|c|}{ Cost Category } & Estimated Cost (Dollars) \\
\hline \hline Design/Engineering & $200 \mathrm{~K}$ \\
\hline Material (from Table 6.1) & $150 \mathrm{~K}$ \\
\hline Installation & $400 \mathrm{~K}$ \\
\hline Testing & $150 \mathrm{~K}$ \\
\hline Operations & $200 \mathrm{~K}$ \\
\hline $\begin{array}{l}\text { Old Equipment Removal, Decon } \\
\text { and Waste Disposal }\end{array}$ & $250 \mathrm{~K}$ \\
\hline Management and Overheads & $100 \mathrm{~K}$ \\
\hline Contingency Plan & $200 \mathrm{~K}$ \\
\hline \hline Total & $1,450 \mathrm{~K}$ \\
\hline
\end{tabular}

